\title{
The Potential for Cancer Immunotherapy in Targeting Surgery-Induced Natural Killer Cell Dysfunction
}

\author{
Marisa Market ${ }^{1, *}$, Katherine E. Baxter $^{1}$, Leonard Angka ${ }^{1} \mathbb{(}$, Michael A. Kennedy ${ }^{2} \mathbb{D}$ and \\ Rebecca C. Auer 1,2,* \\ 1 Department of Medicine, University of Ottawa, Ottawa, ON K1H8L1, Canada; \\ kbaxt090@uottawa.ca (K.E.B.); langk069@uottawa.ca (L.A.) \\ 2 Ottawa Hospital Research Institute (OHRI), Ottawa, ON K1G4E3, Canada; mikennedy@ohri.ca \\ * Correspondence: mmark030@uottawa.ca (M.M.); rauer@toh.ca (R.C.A.); \\ Tel.: +613-737-8899 (ext. 72791) (R.C.A.)
}

Received: 23 November 2018; Accepted: 17 December 2018; Published: 20 December 2018

\begin{abstract}
Natural Killer (NK) cells are granular lymphocytes of the innate immune system that are able to recognize and kill tumor cells without undergoing clonal selection. Discovered over 40 years ago, they have since been recognized to possess both cytotoxic and cytokine-producing effector functions. Following trauma, NK cells are suppressed and their effector functions are impaired. This is especially important for cancer patients undergoing the removal of solid tumors, as surgery has shown to contribute to the development of metastasis and cancer recurrence postoperatively. We have recently shown that NK cells are critical mediators in the formation of metastasis after surgery. While research into the mechanism(s) responsible for NK cell dysfunction is ongoing, knowledge of these mechanisms will pave the way for perioperative therapeutics with the potential to improve cancer outcomes by reversing NK cell dysfunction. This review will discuss mechanisms of suppression in the postoperative environment, including hypercoagulability, suppressive soluble factors, the expansion of suppressive cell populations, and how this affects NK cell biology, including modulation of cell surface receptors, the potential for anergy, and immunosuppressive NK cell functions. This review will also outline potential immunotherapies to reverse postoperative NK dysfunction, with the goal of preventing surgery-induced metastasis.
\end{abstract}

Keywords: natural killer cell; surgery; immunosuppression; cancer; metastasis; immunotherapeutics

\section{Natural Killer Cells}

Natural Killer (NK) cells are innate cytotoxic lymphocytes that play a critical role in immune homeostasis by destroying circulating stressed, infected, or transformed cells [1,2]. Mature NK cells comprise $10-15 \%$ of total peripheral blood leukocytes [3] and are described as $\mathrm{CD}^{-} \mathrm{CD}^{-} 4^{-}$ $\mathrm{CD}^{-} 9^{-} \mathrm{CD}^{+} 6^{+} \mathrm{CD} 16^{+}$. Two functional subsets of NK cells can be distinguished based on the cell surface density of CD56 and the low-affinity Fc-receptor CD16 [4,5]. CD56 ${ }^{\text {dim }}$ CD16 ${ }^{+}$cells make up $90 \%$ of peripheral blood and spleen NK cells and are preferentially cytotoxic, whereas most lymph node NK cells are CD56 $6^{\text {bright }} \mathrm{CD} 16^{\mathrm{dim} /-}$ and readily produce cytokines $[4,6]$. Natural Killers do not undergo clonal selection, but instead express germline receptors which integrate activating and inhibitory signals to determine cellular activity. Through a phenomenon known as the "missing-self hypothesis" [7] NK cells are inhibited by the recognition of constitutively expressed self-molecules. Specifically, inhibitory Killer Ig-like receptors (KIRs) and NKG2A-CD94 recognize HLA-class I and HLA-E, respectively [6,8]. Tumour cells downregulate HLA-class I in an attempt to escape T cell mediated responses [9], simultaneously releasing this inhibitory "break" on NK cells. These inhibitory signals are antagonized by activating receptors, which function by the "induced-self recognition 
model" [7,10-12]. Natural Cytotoxicity Receptors (NCRs), NKp30/44/46, and NKG2D are activating receptors that bind stress ligands BAT3, MICA/B, and ULBP1-6 [5,8], which are upregulated in tumor cells [13]. NK cells are therefore perfectly positioned to target tumor cells without immunological priming. NK cell development and activity are also mediated by contact-dependent interactions with other immune cells, including macrophages and dendritic cells, as well as a plethora of soluble factors, such as interleukin (IL)-2, IL-12, IL-15, and IL-18 [14-20]. Upon recognition and activation by a tumor cell, NK cells respond in three ways: (1) They are directly cytotoxic through $\mathrm{Ca}^{2+}$-dependent exocytosis of cytolytic granules, (2) they secrete cytokines with both direct anti-tumor and immunomodulatory properties, and (3) they induce apoptosis through the expression of death receptor ligands [5,7,13,21,22]. NK cells also participate in antibody-dependent cell-mediated cytotoxicity (ADCC) using the Fc receptor CD16 [23].

\section{Dysfunctional NK Cells Mediate Metastasis in the Postoperative Period}

Natural killer cells are critical innate immune cells and as such, their dysfunction has significant biological consequences. The impairment of NK cell effector functions has been recorded in response to physical trauma, including thermal injury [24], spinal cord and brain injury [25,26], surgery [27-31], and in critically ill patients [32]. The magnitude and duration of NK cell dysfunction are determined by the extent of the injury and although this dysfunction is relatively short-lived, there are long-lasting consequences for patients, most notably in terms of infection and recovery rates [30,33]. Immune dysfunction after surgery is even more consequential in cancer patients. Evidence suggests that surgery for the resection of solid tumors may increase rates of disease recurrence, metastasis, and death [34-36]. This relationship between tumor resection and metastasis was first observed in 1913, however only recently has the dysfunction of the cellular immune response been implicated in the regulation of this phenomenon $[27,30,37-40]$. Specifically, NK cell dysfunction is thought to play an essential role in postoperative e metastasis and cancer recurrence. Profound suppression of NK cell cytotoxicity and cytokine secretion, specifically IFN $\gamma$, has been observed on postoperative day (POD) 1 and beyond, and has been correlated with increased metastases in numerous animal models of spontaneous and implanted metastases. Postoperative NK cell dysfunction is also associated with higher rates of cancer recurrence in human patients [27-30,41-45] (Figure 1). Historically, the perioperative administration of immunostimulatory cytokines, such as IL-2 [46], GM-CSF [47,48], TNF $\alpha$ [49], and IFN $\alpha$ [47], have shown promising results in reducing cancer recurrence and metastases. These factors are known to stimulate NK cell activity and therefore, in light of recent studies that highlight the role of NK cell dysfunction in postoperative metastatic formation, the mechanisms of these therapies are more clearly understood.

The mechanism(s) responsible for postoperative NK cell dysfunction are complex and currently incompletely characterized. Knowledge of these mechanisms will pave the way for the development of perioperative immunotherapeutics; an unexploited window of opportunity to reduce metastasis and cancer recurrence in surgical oncology patients [36]. This review will discuss in detail mechanisms of NK cell suppression in the postoperative environment and the impact on NK cell biology, and will outline potential immunotherapies to reverse postoperative NK cell dysfunction. 


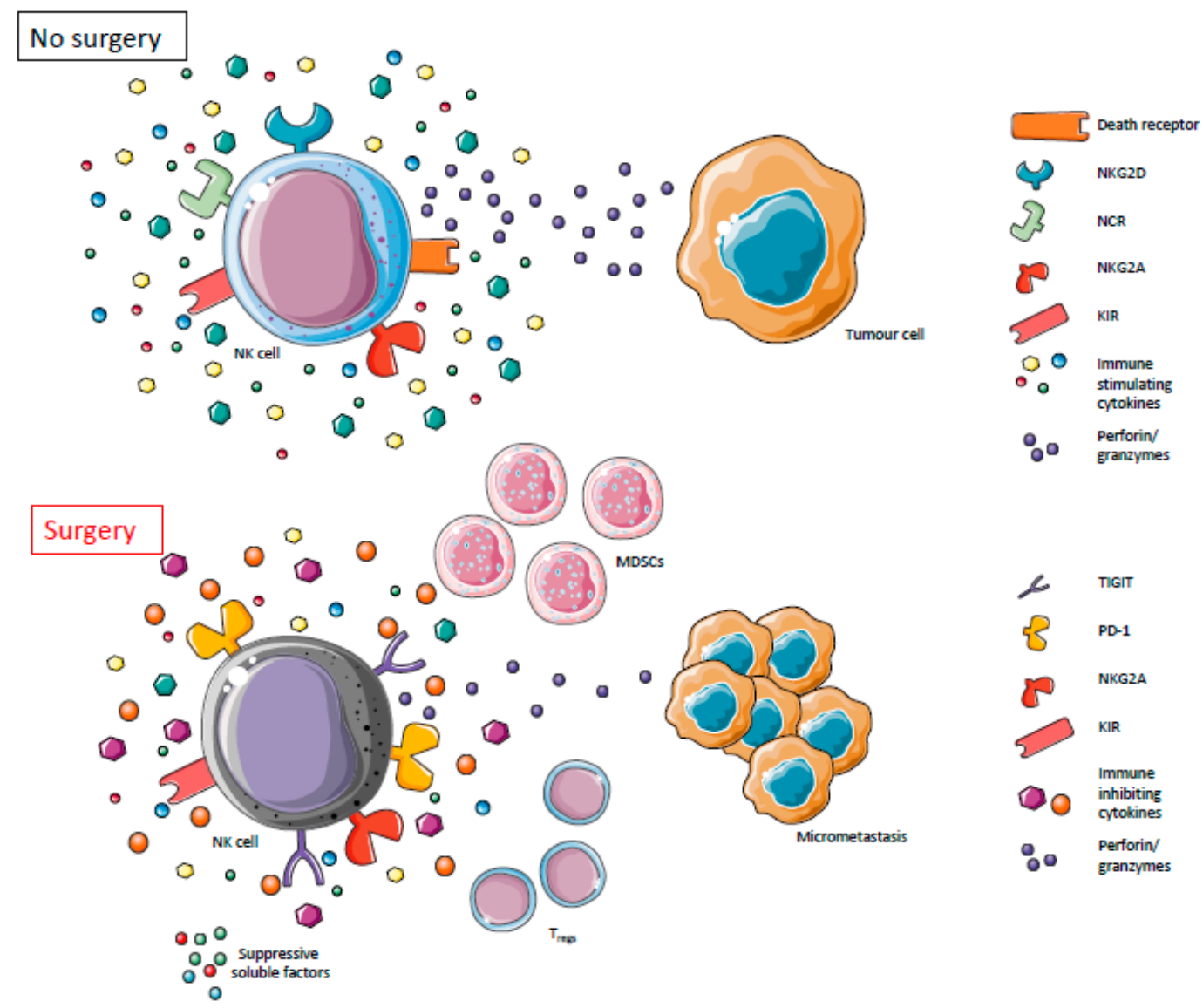

Figure 1. Natural Killer (NK) cells effector functions are impaired postoperatively. In the absence of surgery, NK cells are able to appropriately exert their effector functions thereby directly and indirectly acting to suppress tumor growth and proliferation. In the postoperative period, however, NK cell function is suppressed, leading to a metastatic formation in cancer surgery patients. In our proposed model, surgically stressed NK cells undergo changes in receptor expression mediated by stress-induced soluble factors and surgery-induced suppressive cell populations.

\section{The Postoperative Environment and Potential Therapeutics}

\subsection{The Hypercoagulable State}

Surgical stress results in a dynamic postoperative environment characterized by hypercoagulability, the release of anti-inflammatory factors, and the expansion of immunosuppressive cell populations that may be responsible for the induction of NK cell dysfunction.

The relationship between the coagulation system and cancer progression has been well characterized. Dysregulation of matrix metalloproteases promotes tumor cell migration and metastasis as a result of increased tissue factor, fibrin, and thrombin. Furthermore, angiogenesis is induced by plasmin and vascular endothelial growth factor (VEGF), which can be released from activated platelets, as well as tumor cells [50-56]. Moreover, surgery and cancer, independently, induce a hypercoagulable state characterized by fibrin and platelet clots around tumor cells, resulting in tumor cell emboli (TCE) that impair NK cell-mediated tumor clearance [57]. Lison et al. studied the timing of this dysfunction and found that most clotting factors were profoundly reduced on POD1 until POD3, while fibrinogen, factor VIII, and von Willebrand factor increased continuously starting on POD2, although no significant change was observed in global coagulation tests (prothrombin time (PT) and activated partial thromboplastin time (aPTT)) [58]. Furthermore, Ulrych et al. found that this hypercoagulation lasted until 28-30 days postoperatively in patients undergoing surgery for benign disease [59]. The mechanism of robust adhesion of platelets to tumor cells is largely dependent on the 
expression of P-selectin (CD62P) on activated platelets [60-62]. Cuiling et al. showed that deletion of P-selectin suppressed intestinal tumor growth in spontaneous intestinal tumor mouse models [62]. Interestingly, they also described a mechanism whereby platelet adhesion to tumor cells induces angiogenesis through the secretion of VEGF [60]. Seth et al. investigated metastasis in a murine model of surgical stress and found that surgical stress increased pulmonary metastasis and promoted coagulation [57]. Furthermore, these effects were not mouse-strain or cell-type specific. They found that both factor Xa (the activated form of thrombokinase, which cleaves prothrombin to thrombin) and P-selectin increased postoperatively and mirror the pro-metastatic timeline of surgery. To determine the mechanism of increased metastasis they assessed the association of fibrin and platelet clots with TCE in the lungs of surgically stressed mice and found a 2-fold increase in platelet clot formation and a 3-fold increase in the percent of TCE associated with fibrin when compared with no-surgery mice [57]. They tested five anti-coagulants with different mechanisms of action (tinzaparin, deltaparin, hirudin, warfarin, and platelet depletion using $\alpha$-platelet GPIb $\alpha$ ). All perioperative anticoagulants attenuated the formation of these clots in surgically stressed mice [57]. However, the increased association of fibrin and platelet clots with TCE was not observed when mice were pre-treated with heparin, a P-selectin inhibitor. In addition, to investigate the role of NK cells in TCE clearance, an adoptive transfer using donor NK cells from surgically-stressed and control mice was performed. Mice that had received surgically-stressed NK cells had significantly more metastasis three days after tumor cell injection. Furthermore, low-molecular-weight heparin (LMWH) was not able to attenuate metastasis in NK cell-depleted surgically stressed mice [57]. In addition, various other studies have also shown that heparin can reduce metastatic formation in murine models [62-64]. In patients with solid malignancies, prophylactic or therapeutic doses of LMWH in combination with standard therapy has proven to increase survival in some cancer patients [65-67]. In 1993 Kingston et al. analyzed the effects of the topoisomerase II inhibitor Razoxane and perioperative subcutaneous heparin on survival in a cohort of 603 colorectal cancer patients [66]. They observed a reduction in the risk of an event (recurrence or death) of $22 \%$ (95\% CI: 3-37\%) in heparin-treated patients. Additionally, von Templehoff et al. compared the effects of LMWH (Certoparin) versus unfractionated heparin on cancer survival in 160 breast and pelvic cancer patients and observed increased long-term survival among the LMWH-treated cohort [67]. Lazo-Langner et al. conducted a systematic review and meta-analysis of the effects of LMWH on cancer survival in 2007 [65]. They analyzed four studies for a total of 898 patients with solid tumors who were randomized to receive LMWH, placebo, or no intervention. The one-year mortality favoured patients receiving LMWH (risk ratio (RR) of death $=0.87$ (95\% CI: 0.77-0.99)). Moreover, patients with advanced disease (stages III and IV) also observed decreased mortality when administered LMWH (RR $=0.89$ (95\% CI: 0.80-0.99)) [65]. For these reasons, our group is conducting a phase 3 clinical trial whereby colorectal cancer surgery patients receive perioperative LMWH in an effort to reduce postoperative metastasis (PERIOP-01) [68].

\subsection{The Release of Anti-Inflammatory Soluble Factors}

Surgical stress results in an increase in suppressive soluble factors, such as anti-inflammatory cytokines and stress-related cortisol, prostaglandins, and catecholamines that may potentiate NK cell dysfunction. IL-6 and TGF $\beta$ are anti-inflammatory cytokines that have been shown to negatively regulate NK cell function [69-72]. IL-6 has both pro- and anti-inflammatory effects, but plays a predominantly anti-inflammatory role in the postoperative period [73] leading to reduced NK cell cytotoxicity through decreased perforin and granzyme production [74-77]. While there is a paucity of research into postoperative TGF $\beta$, it is known to inhibit NK cell activation by downregulating the expression of activating NK cell receptors NKG2D, NKp30, and 2B4 [72,78-81]. Interestingly, IL-6 and TGF $\beta$ engage in a positive feedback loop resulting in heightened expression of each cytokine [82-84]. Stress-related factors with well-documented NK cell inhibitory functions, such as cortisol, prostaglandins, and catecholamines, are also increased postoperatively $[85,86]$. Strategies which aim to inhibit the release of these factors in response to surgical stress or antagonize their effects 
on NK cell function provide potential avenues for improving NK cell function in the perioperative period. Specifically, prostaglandin E2 (PGE2) exerts its effects directly on murine NK cells through four endogenous PGE2 receptors EP1-4 [87]. The small molecule inhibitor RQ-15986 has been shown to block EP4-mediated inhibition of NK cell function in vitro and in vivo [88]. Cyclooxygenase (COX)-2 is an enzyme that is responsible for the formation of prostaglandins from cell membrane phospholipids. Promising results in ongoing clinical studies where COX-2 inhibitors were used in conjunction with $\beta$-adrenergic receptor antagonists have provided evidence that pharmacological blockade of these suppressive soluble factors is responsible for the improved immune function and reduced metastasis [89-92]. Shaashua et al. investigated the use of propranolol ( $\beta$-Blocker) and etolodac (COX-2 inhibitor) during the perioperative period in breast cancer patients and showed normalization of pre-surgical IL-6 and C-reactive protein levels, decreased epithelial-to-mesenchymal transition, and decreased tumor-infiltrating monocytes [91]. Currently, a multicentre randomized clinical trial to assess immunosuppression and cancer recurrence in colorectal cancer surgery patients treated with a $\beta$-adrenergic receptor antagonist and a COX-2 inhibitor is currently underway $[90,93]$. In addition to blocking the production of suppressive factors, other groups have explored the potential of using monoclonal antibodies or small molecules to antagonize NK cell receptors for soluble factors like IL-6, TGF $\beta$, and PGE2 $[76,88,94]$. For example, the small molecule TGF $\beta$ receptor kinase inhibitor LY2157299 is able to mitigate the immunosuppressive tumor environment and preserve NK cytotoxic effector functions in vivo [94]. Finally, NK cell stimulating factors, such as IL-2, could be used in conjunction with these therapeutics in order to tip the balance and overcome the inhibitory signals from suppressive soluble factors in the postoperative environment.

\subsection{The Expansion of Immunosuppressive Populations}

\subsubsection{Myeloid-Derived Suppressor Cells}

One of the greatest changes to occur postoperatively is the expansion of suppressive immune cell populations, specifically myeloid-derived suppressor cells (MDSCs) and regulatory $\mathrm{T}$ cells ( $\mathrm{T}_{\text {regs }}$ ).

MDSCs are a heterogeneous population of immature immunoregulatory cells of the myeloid lineage. They can be either granulocytic/polymorphonuclear-, monocytic-, or early-stage MDSCs and have been reported to accumulate under various pathological conditions, such as cancer, burns, sepsis, infections, and following physical or surgical trauma [95-102]. These cells are characterized by myeloid specific markers, such as CD33 and CD11b, are negative for lineage markers (CD3, CD56, CD19), and they have little-to-no expression of HLA-DR in humans [103]. However, MDSCs are ultimately defined by their ability to suppress the activity of immune cells, such as T cells and NK cells [103].

Following cancer surgery, MDSCs rapidly expand in mice [101] and humans [104] and may play a major role in postoperative NK cell suppression. While multiple MDSC-mediated mechanisms of suppression have been described, the mechanism(s) by which MDSCs inhibit NK cell function in the postoperative period have yet to be elucidated. It is well described that after a traumatic injury or wounding, the body enters a state of emergency myelopoiesis whereby immature granulocytes and monocytes are rapidly generated and mobilized to sites of stress $[105,106]$. Recent studies from our group and others have reported that these myeloid cells possess an immunosuppressive phenotype after surgery and trauma [101,104,107]. In an experimental model of colorectal cancer, Xu et al. showed that surgery results in an increase in CT26 tumor growth with a concomitant increase in MDSCs and decrease in CXCL4 [108]. Interestingly, inoculating CXCL4 over-expressing CT26 tumors resulted in a decrease in MDSC infiltration in vivo and CXCL4 reduced MDSC migration in an in vitro transwell assay [108]. Previously, we have reported an increase in monocyte chemoattractants (MCP-1 and eotaxin-1) and a decrease in lymphocyte chemokines (6C-kine, IP10, and SDF-1) following surgery in mice [41]. These studies highlight the systemic rearrangement of immune cells and the accumulation of MDSCs in response to surgical stress. 
MDSCs can suppress immune cell activity through many mechanisms, however here we will focus specifically on the documented mechanisms by which MDSCs suppress NK cells. Studies have shown that MDSCs can suppress NK cells in either a contact-dependent or independent manner. Sarhan et al. demonstrated that MDSCs isolated from patients with myelodysplastic syndrome suppress NK cell degranulation and IFN $\gamma$ secretion through a contact-dependent mechanism mediated by TIGIT [97]. Anti-TIGIT blocking antibodies or separating cells via a transwell were sufficient to abrogate NK cell suppression [97]. Other groups have demonstrated the ability to prevent MDSC-NK cell suppression using TGF $\beta$ [102] and NKp30 [100] antibodies, or adenosine A2A receptor blockade [95]. Numerous groups have also described contact independent mechanisms of NK cell suppression by MDSCs. A hallmark of MDSCs is their upregulation of iNOS and/or arginase-1 which leads to the generation of nitric oxide (NO) or ornithine, respectively, through the catabolism of L-arginine [103]. A recent study by Stiff et al. showed that MDSCs can impair the Fc-receptor mediated (ADCC) and cytokine-producing effector functions of NK cells through NO production [109]. They were able to rescue NK cell ADCC by treating 4T1 tumor bearing mice with an iNOS inhibitor, NIL [109]. Furthermore, culturing patient MDSCs and NK cells in the presence of NIL restored NK cell ADCC lysis and IFN $\gamma$ production. Interestingly, neutralizing antibodies against TGF $\beta$ and IL-10 were not effective. Lastly, nor-NOHA, the arginase- 1 inhibitor, could improve NK cell ADCC in 4T1 bearing mice [109]. The increase in arginase-1 has been shown to be a major contributor to arginine depletion in the postoperative period [110]. In our murine studies, we have seen that inhibiting PDE5 with Sildenafil was effective in abrogating the suppressive effects of surgery-induced MDSCs on NK cells. In vivo administration of Sildenafil also led to reduced lung metastases following surgery in a murine model [101]. We speculate that this was due to the effect of PDE5 inhibition on MDSC arginase-1 expression. Our group and others have shown that PDE5 inhibitors can prevent MDSC suppression and decrease arginase-1 and iNOS expression [101,111]. We are currently testing the effects of Tadalafil in conjunction with influenza on MDSC function in the first phase $1 \mathrm{~b}$ clinical trial of this strategy (PERIOP-04) [112]. These recent studies have shed light on the multifaceted ways in which MDSCs suppress NK cell function in addition to paving the way for therapeutic development.

The first goal in the development of therapeutics to target MDSCs in the postoperative period is to concretely define the key mechanism(s) by which MDSCs induce NK cell dysfunction. Based on our current knowledge of MDSC-mediated NK cell suppression potential therapeutics would therefore likely benefit from targeting both contact-dependent and independent suppressive mechanisms. Monoclonal antibodies against TIGIT, TGF $\beta$, and NKp30, or blockade of the adenosine A2A receptor would prevent the contact-dependent inhibition of NK cell effector functions. On the other hand, the pharmacologic inhibition of iNOS (1400W) or arginase-1 (norNOHA or CB-1158) activity would modulate soluble NO and arginine to improve NK cell activity [99,113-117]. There is currently an ongoing phase 1/2 clinical trial testing CB-1158 in conjunction with the PD-1 inhibitor Pembrolizumab in patients with solid tumors [118]. However, arginase-1 is important for wound healing $[119,120]$ and therefore perioperative supplementation with arginine, perhaps in combination with other nutrients, such as omega-3 fatty acids, may prove to be more beneficial [121]. Heyland et al. completed a systematic review examining the relationship between enteral nutrition supplemented with immune-enhancing nutrients and infectious complications / mortality rate in critically ill patients [122]. They reviewed 326 titles, abstracts, and articles and analyzed data from 22 randomized trials with a collective 2419 patients and found that immunonutrition was associated with lower infectious complications (pooled risk ratio $(R R)=0.66(95 \%$ CI: 0.54-0.80)). Significantly, commercial formulas with high arginine content showed a more significant reduction in infectious complications with a trend toward a lower mortality rate and surgical patients treated with immunonutrition prior to surgery experienced significant benefit over critically ill patients [122]. Since MDSCs are a population of immature myeloid cells, inducing differentiation with all-trans retinoid acid (atRA) may reduce MDSC levels postoperatively $[104,123]$. Finally, identifying a specific marker for MDSCs that may be used for 
the development of antibody drug conjugates (ADCs) would allow for the selective depletion of the MDSCs, although this would be complicated by the heterogeneity of this suppressive cell population.

\subsubsection{Regulatory T Cells}

$\mathrm{T}_{\text {regs }}$ make up a subset of $\mathrm{T}$ cells with immunosuppressive properties defined by the expression of CD4 and CD25, as well as high levels of the forkhead box P3 (FoxP3) transcription factor [124, 125]. The presence of $T_{\text {regs }}$ in the tumor microenvironment and in circulation in cancer patients is associated with poor prognosis [125-128]. Initially studied for their role in suppressing cytotoxic $\mathrm{T}$ cells [125], $\mathrm{T}_{\text {regs }}$ have been increasingly associated with more widespread immune suppression, including IL-10-mediated suppression of NK cells $[125,129]$. In terms of surgical stress, and due to their close association with the tumor microenvironment, it was initially believed that $T_{\text {regs }}$ would decrease following a major surgery $[127,130]$. When levels of circulating $\mathrm{CD}^{+} \mathrm{CD}^{2} 5^{+} \mathrm{Foxp}^{+}$cells were measured in patient PBMCs immediately following surgery on POD1 and were compared to preoperative levels, the data seemed to consistently agree with this hypothesis [104,124,127,130,131]. However, based on the association of $\mathrm{T}_{\text {regs }}$ and other biological stresses, such as septic shock, Saito et al. extended the blood collection to POD6 [124]. They found that not only did these regulatory subsets increase to levels higher than those observed preoperatively by POD6, the circulating levels of $T_{\text {regs }}$ were also proportional to the level of surgical stress and were directly correlated to the invasiveness of the surgery [124], revealing them to be a novel marker of surgical stress. These $T_{\text {regs }}$ were found to have higher expression levels of FoxP3, as well as increased PD-1 and CTLA-4 expression [104,132].

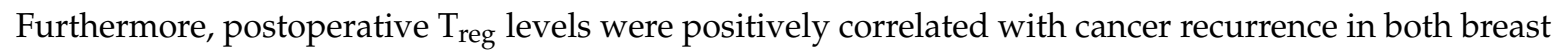
cancer and NSCLC, and may also prove to have prognostic value for other cancer types [104,131,132]. $\mathrm{T}_{\text {regs }}$ are able to functionally block NK cell activity and proliferation through various mechanisms, including cytokine release [129], the use of membrane-bound TGF $\beta$ [133], and out-competing the NK cells for Il-2 $[129,134]$. $T_{\text {reg }}$ function and proliferation are promoted by catecholamines and prostaglandins [14,131,135-137], both of which increase in response to surgical stress [131]. In breast cancer patients receiving radical mastectomies, Zhou et al. found that the $\beta$-Blocker Propranolol, with or without a COX inhibitor, reduced the expansion of $\mathrm{CD} 4^{+} \mathrm{CD}_{25} 5^{+} \mathrm{Foxp} 3^{+}$cells in patient PBMCs on POD7, and that the $T_{\text {regs }}$ in Propranolol-treated patients had reduced suppressive ability [131].

Various immunotherapies have been proposed to decrease $T_{\text {regs }}$ found in cancer patients, and these may be effective in the perioperative period as well. Taking advantage of the contact-dependent mechanisms of suppression, such as $\mathrm{T}_{\text {reg }}$ upregulation of PD-1, CTLA-4, and membrane-bound TGF $\beta$, means that checkpoint blockade could be effective in limiting the effects of $\mathrm{T}_{\text {regs }}$ on NK cell cytotoxicity. Targeting contact independent mechanisms of immunosuppression, such as blocking the activity of secreted cytokines, is also possible therapeutically. However, at this time blocking IL-10 production may prove to have too many side effects, due to its important role in controlling autoimmunity [138]. Since $\mathrm{T}_{\text {regs }}$ may be out-competing NK cells for IL-2, an important cytokine that regulates NK cell function, perioperative administration of IL-2 may be a viable treatment option to boost NK cell function. In fact, Klatte et al. and Böhm et al. investigated preoperative administration of IL-2 in renal cell carcinoma patients and showed improved immune function postoperatively [139,140]. Furthermore, Klatte et al. reported increased tumor-specific survival and progression-free survival in the IL-2 treated group at 1 and 5 years after surgery [139]. However, preoperative IL-2 may need to be employed with caution as Li et al. demonstrated that preoperative IL-2 therapy increased surgically-induced $\mathrm{T}_{\text {reg }}$ numbers and enhanced $\mathrm{T}_{\text {reg }}$ function in patients receiving radical mastectomies, and with melanoma or renal cancers $[132,141]$. Perhaps the most promising method of overcoming

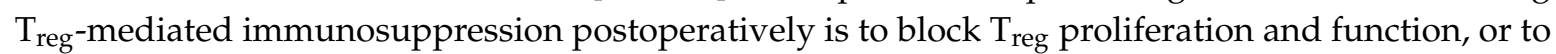
deplete this population from circulation. The combination of COX-2 inhibitors and $\beta$-Blockers have shown some efficacy in this regard [131]. Depletion of $\mathrm{T}_{\text {regs }}$, either through monoclonal antibodies or chemotherapeutics, is another option. In murine studies, CD25 depletion with or without low dose cyclophosphamide has consistently depleted regulatory $\mathrm{T}$ cells in vivo leading to improved 
therapeutics [142-144]. Recently, a number of clinical trials have looked at depleting $\mathrm{T}_{\text {regs }}$ in human cancer patients using either anti-CD25 therapies [145-150] or low dose metronomic administration of cyclophosphamide [151,152]. However, NK cells also express CD25 to form the high-affinity IL-2 receptor and this expression is critical to NK cell function [153]. Therefore, another $\mathrm{T}_{\text {reg }}$ marker that could be used for depletion may need to be identified.

Interestingly, MDSCs were found to interact with $\mathrm{T}_{\text {regs }}$ postoperatively [104]. Monocytic MDSCs (M-MDSCs) that underwent surgery-induced expansion interacted in a contact-dependent manner with $\mathrm{CD} 4^{+} \mathrm{T}$ cells, inducing the expansion of $\mathrm{T}_{\text {regs }}$ that displayed the surgical stress phenotype of high Foxp3 and high surface levels of PD-1. Furthermore, in a mouse model of surgical stress, when atRA was used perioperatively to treat mice, both MDSC and $\mathrm{T}_{\text {reg }}$ levels were reduced postoperatively and fewer lung nodules were observed [104]. Understanding the mechanism of surgical stress-induced $\mathrm{T}_{\text {reg }}$ expansion will allow us to determine which therapeutics to employ in the perioperative period to increase NK cell function. Finally, therapies targeting other immunosuppressive populations may be promising for their synergistic effect on $\mathrm{T}_{\text {regs, }}$ as was observed with M-MDSCs [104].

\section{Surgical Stress and NK Cell Biology}

The complex postoperative immune suppressive environment presents multiple opportunities for therapeutic strategies aimed at reversing NK cell dysfunction. This postoperative milieu undoubtedly affects changes in NK cell biology which can serve as targets for immunotherapeutic development. While the suppression of NK cell effector functions persists for weeks $[27,30,41]$, it is unknown whether dysfunctional NK cells are able to regain their lost functions or are instead replenished by newly differentiated, unimpaired bone-marrow-derived cells. For this reason, the armamentarium of therapeutics aimed at reversing NK cell-mediated postoperative metastasis must target activating/ inhibitory receptors and immune checkpoints, promote NK cell function through external stimuli, and deplete negative immunoregulatory NK cell populations in addition to supplementing endogenous NK cells with ex vivo and allogeneic NK cell populations.

\subsection{Targeting NK Cell Receptor Expression}

If NK cell dysfunction is indeed a temporary state and functionality can be restored, then therapeutic strategies which enhance NK cell function, such as activating receptor agonists and immune checkpoint inhibitors may provide a therapeutic benefit. NK cell activity is controlled through combinatorial synergy of activating and inhibitory receptors to ensure specific and flexible response to external stimuli (as reviewed in $[2,154]$ ). A number of strategies which target these receptor families using soluble ligands, antibody crosslinking, and monoclonal antibodies have been investigated. Recently, Deng et al. have shown that the soluble form of the high-affinity tumor-associated NKG2D ligand MULT1 can enhance anti-tumor activity in murine NK cells [155]. This is presented in stark contrast to other studies, which describe down-modulation of NKG2D in response to sustained engagement with its soluble or membrane-bound ligands (as reviewed in [156]). These studies suggest that blocking prolonged NKG2D-ligand interactions, perhaps with monoclonal antibodies or small molecule inhibitors, may prevent the downregulation of this activating receptor. Furthermore, NKG2D ligand expression is regulated by DNA damage repair pathways, cytokines, and TLR signaling and can be controlled by pharmacological proteasome inhibitors and histone deacetylase inhibitors [157-161]. Upon investigation of NKp30 and a soluble form of its tumor-derived ligand B7-H6, Semeraro et al. suggest that NK cell activity may be improved by the neutralization of sB7-H6 in conjunction with activating NKp30 mAbs [162]. In addition to activating receptors, NK cells also express co-activating receptors, such as DNAM-1 and 2B4, which are crucial to NK cell function. Activation by monoclonal antibodies of $2 \mathrm{~B} 4$ can stimulate IFN $\gamma$ production and cytolytic activity in vitro [163], however, cytotoxicity was augmented if 2B4 and DNAM-1 were targeted together, suggesting that immunotherapeutic development should focus on preserving activating receptor expression, as well as targeting synergistic receptor pairs [2,163]. Positive results 
have also been observed in preclinical models using mAbs to target costimulatory receptors CD137 and CD27 [164-169]. Downregulation of stress-induced ligands by tumor cells is an important escape mechanism from NK cells [2,170]. Therefore, targeting activating receptors will not only enhance NK cell activity after surgery, but circumvent immune evasion mechanisms evolved in tumor cells.

As an alternative to targeting the repertoire of NK activating receptors, recent studies have suggested that blocking engagement/ signaling through inhibitory receptors can similarly improve NK cell function. This is a particularly attractive scenario given the clinical success of immune checkpoint blockade in restoring suppressed $\mathrm{T}$ cell functions. The surface receptors that inhibit NK cell function through the binding of constitutive self-signals are excellent targets for analogous checkpoint inhibition. The anti-KIR mAb Lirilumab is currently being used in clinical trials as a monotherapy or in combination with other checkpoint inhibitors against hematological and solid malignancies $[2,171,172]$. Gallois et al. showed that NK cell exhaustion was reversed in metastatic melanoma patients by blocking the activity of TIM-3 in vitro [173]. PD-1 expression has also been identified on NK cells and PD-1/PD-L1 blockade releases NK cell inhibition resulting in enhanced anti-tumor activity in various mouse models of cancer [174,175]. Furthermore, Benson et al. showed the enhanced function of human NK cells in vitro against multiple myeloma using the novel anti-PD-1 antibody CT-011 [176]. Anti-PD-1 therapies are also being investigated for the treatment of post-traumatic immunosuppression (PTI) in sepsis [177]. If postoperative NK cell functional suppression is mediated by an upregulation of inhibitory receptor expression and activity, anti-immune checkpoint therapeutics may be crucial in reversing this dysfunction.

\subsection{Promoters of NK Cell Function}

NK cell activity can be modulated by more than just activating and inhibitory cell surface receptors. Depletion of arginine, a conditionally essential amino acid, has been shown to impair NK cell cytotoxic potential and the expanded MDSC population uses arginase- 1 to deplete arginine postoperatively [178]. Interestingly, arginine supplementation is one of the treatments for PTI following surgery in non-cancer patients [179]. For this reason, we are conducting a clinical trial investigating a perioperative nutritional arginine supplement on NK cell activity postoperatively (PERIOP-02) [180]. NK cells also recognize virally infected cells, meaning that NK cell activity can be stimulated by the recognition of a virus, such as in the administration of oncolytic viruses (OVs) or vaccines. Tai et al. administered oncolytic parapoxvirus ovis (ORFV) and vaccinia virus (JX-594) perioperatively in a murine model of surgical stress and reversed NK cell suppression, as well as NK-dependent metastatic formation [27]. Furthermore, in the same murine model of surgical stress preoperative administration of influenza vaccination prevented postoperative NK cell dysfunction, as measured by tumor dissemination [101]. This vaccine modulated NK cell activity through dendritic cell-derived IFN $\alpha$, as postoperative NK cells were still dysfunctional in IFN $\alpha$ receptor-deficient mice [101]. Thus, therapeutics should aim to combine direct targeting of changes in NK cell biology with external stimuli that may support or promote NK cell activity.

\subsection{The Suppressive NK Cell}

Changes in NK cell biology may also lead to the expansion of a population of immunosuppressive regulatory NK cells. Moore et al. first described the ability of NK cells to secrete the immunosuppressive cytokine IL-10 in 2001, and since then regulatory NK cells have been described in the settings of a variety of infections and cancers [6,181-184]. This phenotype switch, characterized by the ability to negatively regulate the innate and adaptive immune responses, appears to occur only in response to systemic and not local phenomena [182,184,185]. Jiang et al. describe an IL- $10^{+} \mathrm{TGF}^{+}$NK cell population that is expanded during HIV infection and Perona et al. have characterized IL-10-secreting NK cells in response to systemic T. gondii and L. monocytogenes [182,185]. Furthermore, Terme et al. identified tumor-derived IL-18-induced $\mathrm{Kit}^{+} \mathrm{CD} 11 \mathrm{~b}{ }^{-} \mathrm{NK}$ cells that overexpress B7-H1/PD-L1 and promote tumor growth in two models of pulmonary metastasis [184]. 
Therefore, although the emergence of this population in the postoperative period has not been evaluated to date, it is possible that surgical stress induces the expansion of regulatory NK cells capable of suppressing both innate and adaptive immune responses. Finally, provided a regulatory NK cell population is in fact upregulated after surgery, a more complete identification of markers to define regulatory NK cells would be useful in the development of mAbs or ADCs to selectively inhibit or deplete this population postoperatively.

\subsection{The Unresponsive NK Cell}

The ability of therapeutic strategies targeting the activating or inhibitory receptors to reverse surgical stress-induced NK cell dysfunction is dependent upon whether NK cells can mount an appropriate cellular response to receptor engagement. This will not be the case if postoperative NK cells are functionally hyporesponsive or anergic. If surgically-stressed NK cells are incapable of regaining appropriate effector functions and instead have become anergic, therapies may include either induction of bone marrow progenitor proliferation (for new NK cell production) or adoptive cell transfer using autologous, allogeneic, or genetically engineered NK cell populations, in combination with ex vivo cultivation and in vivo cytokine therapies. NK cell differentiation from HSCs in the bone marrow has been well characterized and is controlled by various cytokines, including fms-like tyrosine kinase 3 ligand (FL), kit ligand (KL), IL-3, IL-12, IL-18, and common- $\gamma$ chain family cytokines [186]. New NK cells produced from the bone marrow in the postoperative period may not exhibit the functional suppression displayed by mature NK cells present in the periphery during surgical stress. Zheng et al. present a manufacturing scheme for "off-the-shelf" universal KIR ${ }^{-}$NK cells derived from induced pluripotent stem cells (iPSCs) which could be used postoperatively to deliver NK cells with intact effector functions [187]. Due to the innate ability of NK cells to recognize transformed cells, the adoptive transfer of NK cells, whether patient or donor-derived, has been investigated to treat a plethora of malignancies, including breast cancer, lymphoma, colorectal cancer, and melanoma [188]. However, long-term expansion protocols are still under development in an effort to produce clinical-grade NK cells [188]. Areas of importance include the source of the NK cells, cytokine stimulation, and cell culture medium in order to produce clinically relevant NK cell numbers with good purity, viability, and uncompromised anti-tumor activity $[188,189]$. Possible sources of NK cells include isolation from peripheral blood mononuclear cells (PBMCs) by apheresis or ficoll separation, stimulation, and differentiation from HSCs or iPSCs, or NK cell lines, with NK92s being the most widely studied. This isolation would be followed by NK cell expansion using feeder cells, stimulant cytokines, or both $[187,188,190-204]$. Numerous cytokines have been investigated for this purpose, including IL-2, IL-15, IL-21, IL-12, and IL-18 [189,195,205-207]. Due to the short half-life of IL-2 in serum (10 min), Nagashima et al. engineered NK cells to produce IL-2 resulting in a constant supply of IL-2 in vivo [208]. NK cells can also be genetically engineered to express chimeric antigen receptors (so-called "CAR-NKs") to specifically target tumor antigens with less toxicity than CAR-T cells [209]. Thus, adoptive NK cell transfer using ex vivo expanded and activated genetically engineered NK cells could not only circumvent surgical stress-induced NK cell dysfunction, thereby preventing cancer recurrence, but could also lead to the effective targeting of residual cancer cells postoperatively. There are, however, questions about the practicality and feasibility of this type of treatment for surgery patients.

\section{Summary and Where to Go from Here}

Natural Killer cells are innate lymphocytes with cytotoxic, cytokine-secreting, and apoptosis-inducing effector functions that play a critical role in the anti-tumor immune response. Although tumor removal is a necessary intervention in the treatment of solid malignancies, surgery is associated with increased metastasis and cancer recurrence. Suppression of the cellular immune response, specifically NK cells, is responsible for this phenomenon. The use of NK-boosting therapies, such as IL-2 or IFN $\alpha$, in the perioperative period has shown promising results. However, there is 
untapped potential in the use of immunotherapies to reverse or prevent surgical stress-induced NK cell dysfunction. Postoperative hypercoagulability, the release of suppressive soluble factors, and the expansion of suppressive cell populations create an immunosuppressive environment under which NK cells cannot exert their effector functions (Figure 2). This results in altered NK cell biology: Downregulation of activating receptors/upregulation of inhibitory receptors and immune checkpoints, induction of anergy resulting in an inability to respond to extracellular signals, or phenotype switching/expansion of immunosuppressive NK cell populations. Individually, each of these potential mechanisms of NK cell dysfunction provides an opportunity for immunotherapeutic intervention. However, NK cell dysfunction in the postoperative period is more likely a complex combination of an immunosuppressive environment and changes in NK cell biology. Perioperative combination therapy in cancer surgery patients will therefore be the most promising avenue for the prevention of cancer recurrence. We are currently conducting a phase $1 \mathrm{~b}$ clinical trial in which a carefully selected promising perioperative immunomodulatory regimen is aimed at preventing MDSC suppression of NK cell function using Tadalafil while simultaneously activating NK cells using influenza vaccination to safely and effectively reverse the effects of surgical stress on NK cell function (PERIOP-04) [112]. The future of immunotherapeutics in cancer and specifically in modulating immunosuppression in the postoperative period should focus on combination therapies that target not only NK cell biology, but also the immunosuppressive environment induced by surgical stress to reduce rates of metastasis and cancer recurrence for all surgical oncology patients.

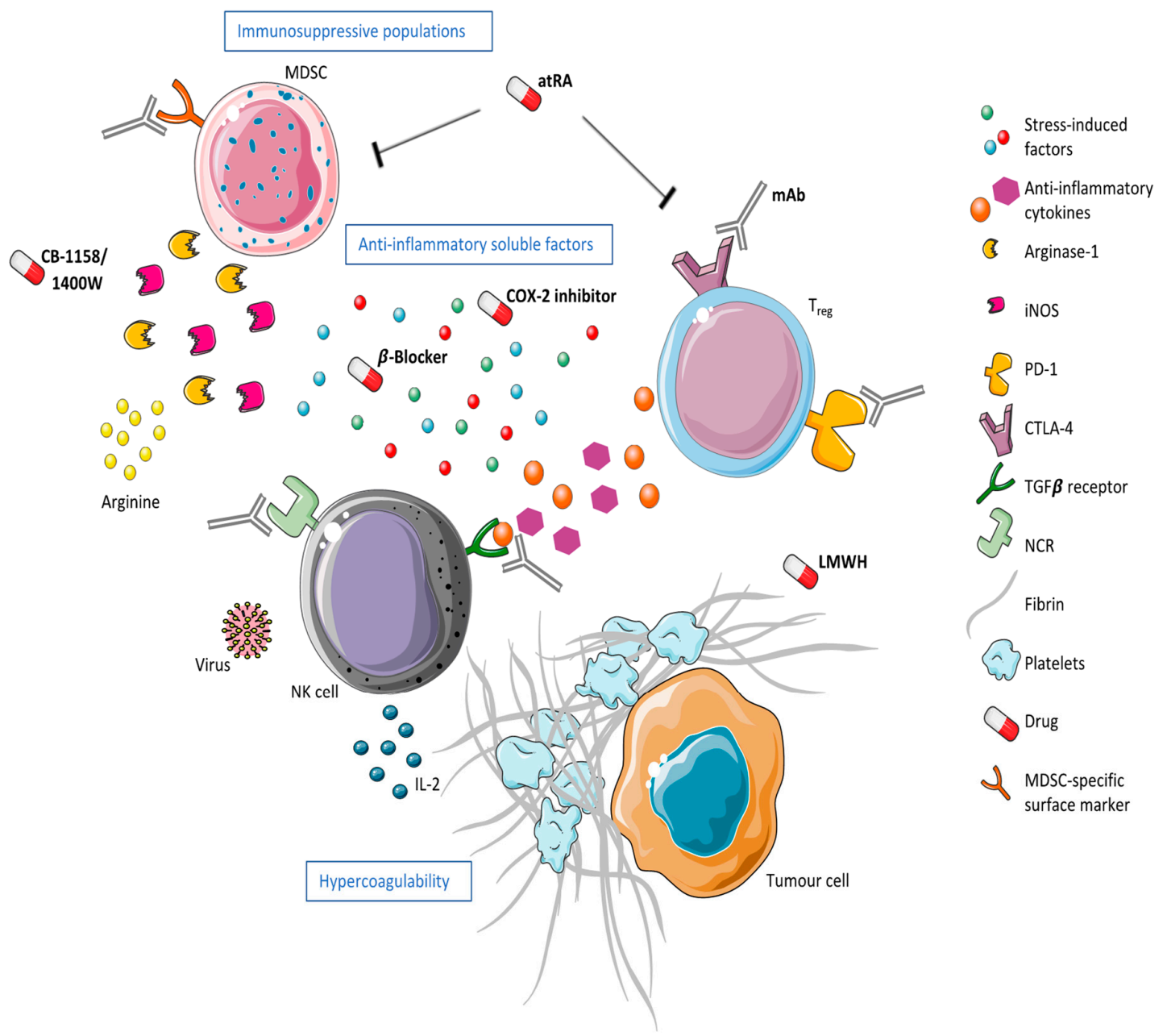

Figure 2. A suppressive environment alters NK cell biology in the postoperative period. A hypercoagulable state physically sequesters tumor cells from NK cells while soluble factors, such as anti-inflammatory cytokines and stress-related factors, as well as immunosuppressive MDSC and 
$\mathrm{T}_{\text {reg }}$ populations suppress NK cell activity postoperatively. This figure outlines potential therapeutics targeting extracellular and intracellular changes as a result of surgical stress. Low-molecular-weight heparin (LMWH) can inhibit P-selectin-mediated adhesion of activated platelets to tumor cells, thereby reducing tumor cell emboli. Pharmacological therapeutics such as CB-1158 or $1400 \mathrm{~W}$ could be used to inhibit arginase- 1 or iNOS, MDSC-derived enzymes responsible for increased nitric oxide (NO) and reduced arginine postoperatively. COX-2 inhibitors could be used in conjunction with $\beta$-Blockers to inhibit the formation and release of stress-induced prostaglandins. All-trans retinoid acid (atRA) could be used to induce MDSC differentiation and/or deplete $\mathrm{T}_{\text {regs. }}$. Monoclonal antibodies (mAb) could be employed to inhibit or activate receptors on the surface of immune cells, including NK cells, MDSCs, and $\mathrm{T}_{\text {regs }}$, in order to modulate their activity. Viral vaccines or oncolytic viruses could be used to promote NK cell activity against micrometastases. Finally, the administration of perioperative cytokines, such as IL-2, could boost NK cell function in the postoperative period.

Author Contributions: M.M., K.E.B., and L.A. wrote this review, in order of contribution. M.M., M.A.K. and R.C.A. conceived the focus and scope of this review.

Funding: We thank the Cancer Research Society (CRS), the Canadian Cancer Society Research Institute (CCSRI), the Canadian Institute of Health Research (CIHR), the University of Ottawa Ontario Graduate Scholarship (OGS), and Gateway for Cancer Research for their financial support funding.

Conflicts of Interest: The authors declare no conflict of interest.

\section{References}

1. Baginska, J.; Viry, E.; Paggetti, J.; Medves, S.; Berchem, G.; Moussay, E.; Janji, B. The critical role of the tumor microenvironment in shaping natural killer cell-mediated anti-tumor immunity. Front. Immunol. 2013, 4, 490. [CrossRef] [PubMed]

2. Chester, C.; Fritsch, K.; Kohrt, H.E. Natural Killer Cell Immunomodulation: Targeting Activating, Inhibitory, and Co-stimulatory Receptor Signaling for Cancer Immunotherapy. Front. Immunol. 2015, 6, 601. [CrossRef] [PubMed]

3. Maghazachi, A.A. Compartmentalization of human natural killer cells. Mol. Immunol. 2005, 42, 523-529. [CrossRef] [PubMed]

4. Cooper, M.A.; Fehniger, T.A.; Caligiuri, M.A. The biology of human natural killer-cell subsets. Trends Immunol. 2001, 22, 633-640. [CrossRef]

5. Vivier, E.; Tomasello, E.; Baratin, M.; Walzer, T.; Ugolini, S. Functions of natural killer cells. Nat. Immunol. 2008, 9, 503-510. [CrossRef]

6. Vivier, E.; Ugolini, S. Regulatory natural killer cells: New players in the IL-10 anti-inflammatory response. Cell Host Microbe 2009, 6, 493-495. [CrossRef] [PubMed]

7. Waldhauer, I.; Steinle, A. NK cells and cancer immunosurveillance. Oncogene 2008, 27, 5932-5943. [CrossRef]

8. Lanier, L.L. NK cell recognition. Annu. Rev. Immunol. 2005, 23, 225-274. [CrossRef]

9. Bubeník, J. Tumour MHC class I downregulation and immunotherapy (Review). Oncol. Rep. 2003, 10, 2005-2008. [CrossRef]

10. Diefenbach, A.; Raulet, D.H. Strategies for target cell recognition by natural killer cells. Immunol. Rev. 2001, 181, 170-184. [CrossRef]

11. Raulet, D.H. Interplay of natural killer cells and their receptors with the adaptive immune response. Nat. Immunol. 2004, 5, 996-1002. [CrossRef] [PubMed]

12. Bauer, S.; Groh, V.; Wu, J.; Steinle, A.; Phillips, J.H.; Lanier, L.L.; Spies, T. Activation of NK cells and T cells by NKG2D, a receptor for stress-inducible MICA. Science 1999, 285, 727-729. [CrossRef] [PubMed]

13. Long, E.O. Tumor cell recognition by natural killer cells. Semin. Cancer Biol. 2002, 12, 57-61. [CrossRef] [PubMed]

14. Kalinski, P. Regulation of immune responses by prostaglandin E2. J. Immunol. 2012, 188, 21-28. [CrossRef] [PubMed]

15. Ikeda, H.; Old, L.J.; Schreiber, R.D. The roles of IFN $\gamma$ in protection against tumor development and cancer immunoediting. Cytokine Growth Factor Rev. 2002, 13, 95-109. [CrossRef] 
16. Yamamoto, T.; Kimura, T.; Ueta, E.; Tatemoto, Y.; Osaki, T. Characteristic cytokine generation patterns in cancer cells and infiltrating lymphocytes in oral squamous cell carcinomas and the influence of chemoradiation combined with immunotherapy on these patterns. Oncology 2003, 64, 407-415. [CrossRef]

17. Michel, T.; Hentges, F.; Zimmer, J. Consequences of the crosstalk between monocytes/macrophages and natural killer cells. Front. Immunol. 2012, 3, 403. [CrossRef] [PubMed]

18. Yuan, D.; Koh, C.Y.; Wilder, J.A. Interactions between B lymphocytes and NK cells. FASEB J. 1994, 8, 1012-1018. [CrossRef]

19. Fung, M.M.; Rohwer, F.; McGuire, K.L. IL-2 activation of a PI3K-dependent STAT3 serine phosphorylation pathway in primary human T cells. Cell Signal. 2003, 15, 625-636. [CrossRef]

20. Marçais, A.; Cherfils-Vicini, J.; Viant, C.; Degouve, S.; Viel, S.; Fenis, A.; Rabilloud, J.; Mayol, K.; Tavares, A.; Bienvenu, J.; et al. The metabolic checkpoint kinase mTOR is essential for IL-15 signaling during the development and activation of NK cells. Nat. Immunol. 2014, 15, 749-757. [CrossRef]

21. Zamai, L.; Ahmad, M.; Bennett, I.M.; Azzoni, L.; Alnemri, E.S.; Perussia, B. Natural killer (NK) cell-mediated cytotoxicity: Differential use of TRAIL and Fas ligand by immature and mature primary human NK cells. J. Exp. Med. 1998, 188, 2375-2380. [CrossRef] [PubMed]

22. Langers, I.; Renoux, V.M.; Thiry, M.; Delvenne, P.; Jacobs, N. Natural killer cells: Role in local tumor growth and metastasis. Biologics 2012, 6, 73-82. [PubMed]

23. Terunuma, H.; Deng, X.; Dewan, Z.; Fujimoto, S.; Yamamoto, N. Potential Role of NK Cells in the Induction of Immune Responses: Implications for NK Cell-Based Immunotherapy for Cancers and Viral Infections. Int. Rev. Immunol. 2008, 27, 93-110. [CrossRef] [PubMed]

24. Blazar, B.A.; Rodrick, M.L.; O’Mahony, J.B.; Wood, J.J.; Bessey, P.Q.; Wilmore, D.W.; Mannick, J.A. Suppression of natural killer-cell function in humans following thermal and traumatic injury. J. Clin. Immunol. 1986, 6, 26-36. [CrossRef] [PubMed]

25. Iversen, P.O.; Hjeltnes, N.; Holm, B.; Flatebo, T.; Strom-Gundersen, I.; Ronning, W.; Stanghelle, J.; Benestad, H.B. Depressed immunity and impaired proliferation of hematopoietic progenitor cells in patients with complete spinal cord injury. Blood 2000, 96, 2081-2083. [PubMed]

26. Chou, A.; Krukowski, K.; Morganti, J.M.; Riparip, L.-K.; Rosi, S. Persistent Infiltration and Impaired Response of Peripherally-Derived Monocytes after Traumatic Brain Injury in the Aged Brain. Int. J. Mol. Sci. 2018, 19. [CrossRef] [PubMed]

27. Tai, L.-H.; Zhang, J.; Scott, K.J.; de Souza, C.T.; Alkayyal, A.A.; Ananth, A.A.; Sahi, S.; Adair, R.A.; Mahmoud, A.B.; Sad, S.; et al. Perioperative influenza vaccination reduces postoperative metastatic disease by reversing surgery-induced dysfunction in natural killer cells. Clin. Cancer Res. 2013, 19, 5104-5115. [CrossRef] [PubMed]

28. Pollock, R.E.; Lotzová, E.; Stanford, S.D. Mechanism of surgical stress impairment of human perioperative natural killer cell cytotoxicity. Arch. Surg. 1991, 126, 338-342. [CrossRef] [PubMed]

29. Reinhardt, R.; Pohlmann, S.; Kleinertz, H.; Hepner-Schefczyk, M.; Paul, A.; Flohé, S.B. Invasive Surgery Impairs the Regulatory Function of Human CD56 bright Natural Killer Cells in Response to Staphylococcus aureus. Suppression of Interferon- $\gamma$ Synthesis. PLoS ONE 2015, 10, e0130155. [CrossRef] [PubMed]

30. Angka, L.; Martel, A.B.; Kilgour, M.; Jeong, A.; Sadiq, M.; de Souza, C.T.; Baker, L.; Kennedy, M.A.; Kekre, N.; Auer, R.C. Natural Killer Cell IFN $\gamma$ Secretion is Profoundly Suppressed Following Colorectal Cancer Surgery. Ann. Surg. Oncol. 2018, 25, 3747-3754. [CrossRef] [PubMed]

31. Baxevanis, C.N.; Papilas, K.; Dedoussis, G.V.; Pavlis, T.; Papamichail, M. Abnormal cytokine serum levels correlate with impaired cellular immune responses after surgery. Clin. Immunol. Immunopathol. 1994, 71, 82-88. [CrossRef] [PubMed]

32. Kim, M.; Kim, M.; Jeong, H.; Chae, J.S.; Kim, Y.S.; Lee, J.G.; Cho, Y.; Lee, J.H. Hyporesponsiveness of natural killer cells and impaired inflammatory responses in critically ill patients. BMC Immunol. 2017, 18, 48. [CrossRef] [PubMed]

33. Van der Bij, G.J.; Oosterling, S.J.; Beelen, R.H.J.; Meijer, S.; Coffey, J.C.; van Egmond, M. The perioperative period is an underutilized window of therapeutic opportunity in patients with colorectal cancer. Ann. Surg. 2009, 249, 727-734. [CrossRef] [PubMed]

34. Demicheli, R.; Retsky, M.W.; Hrushesky, W.J.M.; Baum, M.; Gukas, I.D. The effects of surgery on tumor growth: A century of investigations. Ann. Oncol. 2008, 19, 1821-1828. [CrossRef] 
35. Baum, M.; Demicheli, R.; Hrushesky, W.; Retsky, M. Does surgery unfavourably perturb the "natural history" of early breast cancer by accelerating the appearance of distant metastases? Eur. J. Cancer 2005, 41, 508-515. [CrossRef] [PubMed]

36. Coffey, J.C.; Wang, J.H.; Smith, M.J.F.; Bouchier-Hayes, D.; Cotter, T.G.; Redmond, H.P. Excisional surgery for cancer cure: Therapy at a cost. Lancet Oncol. 2003, 4, 760-768. [CrossRef]

37. Tyzzer, E.E. Factors in the Production and Growth of tumor Metastases. J. Med. Res. 1913, 28, 309-332.

38. Decker, D.; Schondorf, M.; Bidlingmaier, F.; Hirner, A.; von Ruecker, A.A. Surgical stress induces a shift in the type-1/type-2 T-helper cell balance, suggesting down-regulation of cell-mediated and up-regulation of antibody-mediated immunity commensurate to the trauma. Surgery 1996, 119, 316-325. [CrossRef]

39. Tsuchiya, Y.; Sawada, S.; Yoshioka, I.; Ohashi, Y.; Matsuo, M.; Harimaya, Y.; Tsukada, K.; Saiki, I. Increased surgical stress promotes tumor metastasis. Surgery 2003, 133, 547-555. [CrossRef]

40. Eberhardt, J.M.; Kiran, R.P.; Lavery, I.C. The impact of anastomotic leak and intra-abdominal abscess on cancer-related outcomes after resection for colorectal cancer: A case control study. Dis. Colon Rectum 2009, 52, 380-386. [CrossRef]

41. Tai, L.-H.; de Souza, C.T.; Bélanger, S.; Ly, L.; Alkayyal, A.A.; Zhang, J.; Rintoul, J.L.; Ananth, A.A.; Lam, T.; Breitbach, C.J.; et al. Preventing postoperative metastatic disease by inhibiting surgery-induced dysfunction in natural killer cells. Cancer Res. 2013, 73, 97-107. [CrossRef] [PubMed]

42. Nichols, P.H.; Ramsden, C.W.; Ward, U.; Trejdosiewicz, L.K.; Ambrose, N.S.; Primrose, J.N. Peri-operative modulation of cellular immunity in patients with colorectal cancer. Clin. Exp. Immunol. 1993, 94, 4-10. [CrossRef] [PubMed]

43. Nichols, P.H.; Ramsden, C.W.; Ward, U.; Sedman, P.C.; Primrose, J.N. Perioperative immunotherapy with recombinant interleukin 2 in patients undergoing surgery for colorectal cancer. Cancer Res. 1992, 52, 5765-5769. [PubMed]

44. Deehan, D.J.; Heys, S.D.; Ashby, J.; Eremin, O. Interleukin-2 (IL-2) augments host cellular immune reactivity in the perioperative period in patients with malignant disease. Eur. J. Surg. Oncol. 1995, 21, 16-22. [CrossRef]

45. Houvenaeghel, G.; Bladou, F.; Blache, J.L.; Olive, D.; Monges, G.; Jacquemier, J.; Chaudet, H.; Delpero, J.R.; Guérinel, G. Tolerance and feasibility of perioperative treatment with interferon-alpha $2 \mathrm{a}$ in advanced cancers. Int. Surg. 1997, 82, 165-169. [PubMed]

46. Jain, A.; Slansky, J.E.; Matey, L.C.; Allen, H.E.; Pardoll, D.M.; Schulick, R.D. Synergistic effect of a granulocyte-macrophage colony-stimulating factor-transduced tumor vaccine and systemic interleukin-2 in the treatment of murine colorectal cancer hepatic metastases. Ann. Surg. Oncol. 2003, 10, 810-820. [CrossRef]

47. Oosterling, S.J.; van der Bij, G.J.; Mels, A.K.; Beelen, R.H.J.; Meijer, S.; van Egmond, M.; van Leeuwen, P.A.M. Perioperative IFN-alpha to avoid surgically induced immune suppression in colorectal cancer patients. Histol. Histopathol. 2006, 21, 753-760.

48. Mels, A.K.; Statius Muller, M.G.; van Leeuwen, P.A.M.; von Blomberg, B.M.E.; Scheper, R.J.; Cuesta, M.A.; Beelen, R.H.J.; Meijer, S. Immune-stimulating effects of low-dose perioperative recombinant granulocyte-macrophage colony-stimulating factor in patients operated on for primary colorectal carcinoma. Br. J. Surg. 2001, 88, 539-544. [CrossRef]

49. Sturm, J.W.; Magdeburg, R.; Berger, K.; Petruch, B.; Samel, S.; Bönninghoff, R.; Keese, M.; Hafner, M.; Post, S. Influence of TNFA on the formation of liver metastases in a syngenic mouse model. Int. J. Cancer 2003, 107, 11-21. [CrossRef]

50. Webb, N.J.; Bottomley, M.J.; Watson, C.J.; Brenchley, P.E. Vascular endothelial growth factor (VEGF) is released from platelets during blood clotting: Implications for measurement of circulating VEGF levels in clinical disease. Clin. Sci. 1998, 94, 395-404. [CrossRef]

51. Palumbo, J.S.; Kombrinck, K.W.; Drew, A.F.; Grimes, T.S.; Kiser, J.H.; Degen, J.L.; Bugge, T.H. Fibrinogen is an important determinant of the metastatic potential of circulating tumor cells. Blood 2000, 96, 3302-3309. [PubMed]

52. Palumbo, J.S.; Potter, J.M.; Kaplan, L.S.; Talmage, K.; Jackson, D.G.; Degen, J.L. Spontaneous hematogenous and lymphatic metastasis, but not primary tumor growth or angiogenesis, is diminished in fibrinogen-deficient mice. Cancer Res. 2002, 62, 6966-6972. [PubMed]

53. Palumbo, J.S.; Talmage, K.E.; Liu, H.; La Jeunesse, C.M.; Witte, D.P.; Degen, J.L. Plasminogen supports tumor growth through a fibrinogen-dependent mechanism linked to vascular patency. Blood 2003, 102, 2819-2827. [CrossRef] [PubMed] 
54. Sutherland, D.E.; Weitz, I.C.; Liebman, H.A. Thromboembolic complications of cancer: Epidemiology, pathogenesis, diagnosis, and treatment. Am. J. Hematol. 2003, 72, 43-52. [CrossRef]

55. Rickles, F.R.; Patierno, S.; Fernandez, P.M. Tissue factor, thrombin, and cancer. Chest 2003, 124, 58S-68S. [CrossRef] [PubMed]

56. Sampson, M.T.; Kakkar, A.K. Coagulation proteases and human cancer. Biochem. Soc. Trans. 2002, 30, $201-207$. [CrossRef] [PubMed]

57. Seth, R.; Tai, L.-H.; Falls, T.; de Souza, C.T.; Bell, J.C.; Carrier, M.; Atkins, H.; Boushey, R.; Auer, R.A. Surgical stress promotes the development of cancer metastases by a coagulation-dependent mechanism involving natural killer cells in a murine model. Ann. Surg. 2013, 258, 158-168. [CrossRef] [PubMed]

58. Lison, S.; Weiss, G.; Spannagl, M.; Heindl, B. Postoperative changes in procoagulant factors after major surgery. Blood Coagul. Fibrinolysis 2011, 22, 190-196. [CrossRef] [PubMed]

59. Ulrych, J.; Kvasnicka, T.; Fryba, V.; Komarc, M.; Malikova, I.; Burget, F.; Brzezkova, R.; Kvasnicka, J., Jr.; Krska, Z.; Kvasnicka, J. 28 day post-operative persisted hypercoagulability after surgery for benign diseases: A prospective cohort study. BMC Surg. 2016, 16, 16. [CrossRef]

60. Qi, C.; Li, B.; Guo, S.; Wei, B.; Shao, C.; Li, J.; Yang, Y.; Zhang, Q.; Li, J.; He, X.; et al. P-Selectin-Mediated Adhesion between Platelets and Tumor Cells Promotes Intestinal Tumorigenesis in Apc(Min/+) Mice. Int. J. Biol. Sci. 2015, 11, 679-687. [CrossRef] [PubMed]

61. Stevenson, J.L.; Varki, A.; Borsig, L. Heparin attenuates metastasis mainly due to inhibition of P-and L-selectin, but non-anticoagulant heparins can have additional effects. Thromb. Res. 2007, 120 (Suppl. 2), S107-S111. [CrossRef]

62. Varki, A.; Varki, N.M. P-selectin, carcinoma metastasis and heparin: Novel mechanistic connections with therapeutic implications. Braz. J. Med. Biol. Res. 2001, 34, 711-717. [CrossRef] [PubMed]

63. Borsig, L.; Wong, R.; Feramisco, J.; Nadeau, D.R.; Varki, N.M.; Varki, A. Heparin and cancer revisited: Mechanistic connections involving platelets, P-selectin, carcinoma mucins, and tumor metastasis. Proc. Natl. Acad. Sci. USA 2001, 98, 3352-3357. [CrossRef] [PubMed]

64. Wei, M.; Tai, G.; Gao, Y.; Li, N.; Huang, B.; Zhou, Y.; Hao, S.; Zeng, X. Modified heparin inhibits P-selectin-mediated cell adhesion of human colon carcinoma cells to immobilized platelets under dynamic flow conditions. J. Biol. Chem. 2004, 279, 29202-29210. [CrossRef] [PubMed]

65. Lazo-Langner, A.; Goss, G.D.; Spaans, J.N.; Rodger, M.A. The effect of low-molecular-weight heparin on cancer survival. A systematic review and meta-analysis of randomized trials. J. Thromb. Haemost. 2007, 5, 729-737. [CrossRef]

66. Kingston, R.D.; Fielding, J.W.; Palmer, M.K. Peri-operative heparin: A possible adjuvant to surgery in colo-rectal cancer? Int. J. Colorectal Dis. 1993, 8, 111-115. [CrossRef] [PubMed]

67. Von Tempelhoff, G.F.; Harenberg, J.; Niemann, F.; Hommel, G.; Kirkpatrick, C.J.; Heilmann, L. Effect of low molecular weight heparin (Certoparin) versus unfractionated heparin on cancer survival following breast and pelvic cancer surgery: A prospective randomized double-blind trial. Int. J. Oncol. 2000, 16, 815-824. [CrossRef] [PubMed]

68. Carrier, M.; Auer, R.C. NCT01455831: A Multicentre Randomized Controlled Trial of the Use of Extended Peri-Operative Low Molecular Weight Heparin to Improve Cancer Specific Survival Following Surgical Resection of Colorectal Cancer. Available online: https://clinicaltrials.gov/ct2/show/NCT01455831 (accessed on 26 October 2018).

69. Scheller, J.; Chalaris, A.; Schmidt-Arras, D.; Rose-John, S. The pro- and anti-inflammatory properties of the cytokine interleukin-6. Biochim. Biophys. Acta 2011, 1813, 878-888. [CrossRef] [PubMed]

70. Narita, S.; Tsuchiya, N.; Kumazawa, T.; Maita, S.; Numakura, K.; Obara, T.; Tsuruta, H.; Saito, M.; Inoue, T.; Horikawa, Y.; et al. Comparison of surgical stress in patients undergoing open versus laparoscopic radical prostatectomy by measuring perioperative serum cytokine levels. J. Laparoendosc. Adv. Surg. Tech. A 2013, 23, 33-37. [CrossRef]

71. Shariat, S.F.; Kattan, M.W.; Traxel, E.; Andrews, B.; Zhu, K.; Wheeler, T.M.; Slawin, K.M. Association of preand postoperative plasma levels of transforming growth factor beta(1) and interleukin 6 and its soluble receptor with prostate cancer progression. Clin. Cancer Res. 2004, 10, 1992-1999. [CrossRef]

72. Gao, J.; Duan, Z.; Zhang, L.; Huang, X.; Long, L.; Tu, J.; Liang, H.; Zhang, Y.; Shen, T.; Lu, F. Failure recovery of circulating NKG2D+CD56dimNK cells in HBV-associated hepatocellular carcinoma after hepatectomy predicts early recurrence. Oncoimmunology 2016, 5, e1048061. [CrossRef] [PubMed] 
73. Ferri, M.; Rossi Del Monte, S.; Salerno, G.; Bocchetti, T.; Angeletti, S.; Malisan, F.; Cardelli, P.; Ziparo, V.; Torrisi, M.R.; Visco, V. Recovery of immunological homeostasis positively correlates both with early stages of right-colorectal cancer and laparoscopic surgery. PLoS ONE 2013, 8, e74455. [CrossRef] [PubMed]

74. Scheid, C.; Young, R.; McDermott, R.; Fitzsimmons, L.; Scarffe, J.H.; Stern, P.L. Immune function of patients receiving recombinant human interleukin-6 (IL-6) in a phase I clinical study: Induction of C-reactive protein and $\operatorname{IgE}$ and inhibition of natural killer and lymphokine-activated killer cell activity. Cancer Immunol. Immunother. 1994, 38, 119-126. [PubMed]

75. Kang, Y.-J.; Jeung, I.C.; Park, A.; Park, Y.-J.; Jung, H.; Kim, T.-D.; Lee, H.G.; Choi, I.; Yoon, S.R. An increased level of IL-6 suppresses NK cell activity in peritoneal fluid of patients with endometriosis via regulation of SHP-2 expression. Hum. Reprod. 2014, 29, 2176-2189. [CrossRef] [PubMed]

76. Cifaldi, L.; Prencipe, G.; Caiello, I.; Bracaglia, C.; Locatelli, F.; De Benedetti, F.; Strippoli, R. Inhibition of natural killer cell cytotoxicity by interleukin-6: Implications for the pathogenesis of macrophage activation syndrome. Arthritis Rheumatol. 2015, 67, 3037-3046. [CrossRef] [PubMed]

77. Vredevoe, D.L.; Widawski, M.; Fonarow, G.C.; Hamilton, M.; Martínez-Maza, O.; Gage, J.R. Interleukin-6 (IL-6) expression and natural killer (NK) cell dysfunction and anergy in heart failure. Am. J. Cardiol. 2004, 93, 1007-1011. [CrossRef] [PubMed]

78. Castriconi, R.; Cantoni, C.; Della Chiesa, M.; Vitale, M.; Marcenaro, E.; Conte, R.; Biassoni, R.; Bottino, C.; Moretta, L.; Moretta, A. Transforming growth factor beta 1 inhibits expression of NKp30 and NKG2D receptors: Consequences for the NK-mediated killing of dendritic cells. Proc. Natl. Acad. Sci. USA 2003, 100, 4120-4125. [CrossRef] [PubMed]

79. Sun, C.; Fu, B.; Gao, Y.; Liao, X.; Sun, R.; Tian, Z.; Wei, H. TGF- $\beta 1$ down-regulation of NKG2D/DAP10 and 2B4/SAP expression on human NK cells contributes to HBV persistence. PLoS Pathog. 2012, 8, e1002594. [CrossRef]

80. Crane, C.A.; Han, S.J.; Barry, J.J.; Ahn, B.J.; Lanier, L.L.; Parsa, A.T. TGF-beta downregulates the activating receptor NKG2D on NK cells and CD8+ T cells in glioma patients. Neuro Oncol. 2010, 12, 7-13. [CrossRef]

81. Lee, J.-C.; Lee, K.-M.; Kim, D.-W.; Heo, D.S. Elevated TGF- $\beta 1$ Secretion and Down-Modulation of NKG2D Underlies Impaired NK Cytotoxicity in Cancer Patients. J. Immunol. 2004, 172, 7335-7340. [CrossRef]

82. Zhang, X.L.; Topley, N.; Ito, T.; Phillips, A. Interleukin-6 regulation of transforming growth factor (TGF)-beta receptor compartmentalization and turnover enhances TGF-beta1 signaling. J. Biol. Chem. 2005, 280, 12239-12245. [CrossRef] [PubMed]

83. Turner, M.; Chantry, D.; Feldmann, M. Transforming growth factor beta induces the production of interleukin 6 by human peripheral blood mononuclear cells. Cytokine 1990, 2, 211-216. [CrossRef]

84. Ulich, T.R.; Yin, S.; Guo, K.; Yi, E.S.; Remick, D.; del Castillo, J. Intratracheal injection of endotoxin and cytokines. II. Interleukin-6 and transforming growth factor beta inhibit acute inflammation. Am. J. Pathol. 1991, 138, 1097-1101. [PubMed]

85. Meron, G.; Tishler, Y.; Shaashua, L.; Rosenne, E.; Levi, B.; Melamed, R.; Gotlieb, N.; Matzner, P.; Sorski, L.; Ben-Eliyahu, S. PGE2 suppresses NK activity in vivo directly and through adrenal hormones: Effects that cannot be reflected by ex vivo assessment of NK cytotoxicity. Brain Behav. Immun. 2013, 28, 128-138. [CrossRef] [PubMed]

86. Rosenne, E.; Sorski, L.; Shaashua, L.; Neeman, E.; Matzner, P.; Levi, B.; Ben-Eliyahu, S. In vivo suppression of NK cell cytotoxicity by stress and surgery: Glucocorticoids have a minor role compared to catecholamines and prostaglandins. Brain Behav. Immun. 2014, 37, 207-219. [CrossRef] [PubMed]

87. Holt, D.; Ma, X.; Kundu, N.; Fulton, A. Prostaglandin E(2) (PGE (2)) suppresses natural killer cell function primarily through the PGE(2) receptor EP4. Cancer Immunol. Immunother. 2011, 60, 1577-1586. [CrossRef] [PubMed]

88. Ma, X.; Holt, D.; Kundu, N.; Reader, J.; Goloubeva, O.; Take, Y.; Fulton, A.M. A prostaglandin E (PGE) receptor EP4 antagonist protects natural killer cells from PGE2-mediated immunosuppression and inhibits breast cancer metastasis. Oncoimmunology 2013, 2, e22647. [CrossRef] [PubMed]

89. Choy, C.; Raytis, J.L.; Smith, D.D.; Duenas, M.; Neman, J.; Jandial, R.; Lew, M.W. Inhibition of $\beta 2$-adrenergic receptor reduces triple-negative breast cancer brain metastases: The potential benefit of perioperative $\beta$-blockade. Oncol. Rep. 2016, 35, 3135-3142. [CrossRef] [PubMed]

90. Horowitz, M.; Neeman, E.; Sharon, E.; Ben-Eliyahu, S. Exploiting the critical perioperative period to improve long-term cancer outcomes. Nat. Rev. Clin. Oncol. 2015, 12, 213-226. [CrossRef] [PubMed] 
91. Shaashua, L.; Shabat-Simon, M.; Haldar, R.; Matzner, P.; Zmora, O.; Shabtai, M.; Sharon, E.; Allweis, T.; Barshack, I.; Hayman, L.; et al. Perioperative COX-2 and $\beta$-Adrenergic Blockade Improves Metastatic Biomarkers in Breast Cancer Patients in a Phase-II Randomized Trial. Clin. Cancer Res. 2017, 23, 4651-4661. [CrossRef]

92. Benish, M.; Bartal, I.; Goldfarb, Y.; Levi, B.; Avraham, R.; Raz, A.; Ben-Eliyahu, S. Perioperative use of beta-blockers and COX-2 inhibitors may improve immune competence and reduce the risk of tumor metastasis. Ann. Surg. Oncol. 2008, 15, 2042-2052. [CrossRef] [PubMed]

93. Zmora, O.; Tulchinsky, H.; Wasserberg, N. NCT00888797: Perioperative B-Adrenergic Blocker and a COX2 Inhibitor in Patients Undergoing Resection for Primary Colon and Rectal Cancer: Effect on Tumor Recurrence and Postoperative Immune Perturbations. A Multicenter Randomized Prospective Trial. Available online: https: / clinicaltrials.gov / ct2/show / record/NCT00888797 (accessed on 26 October 2018).

94. Otegbeye, F.; Ojo, E.; Moreton, S.; Mackowski, N.; Lee, D.A.; de Lima, M.; Wald, D.N. Inhibiting TGF-beta signaling preserves the function of highly activated, in vitro expanded natural killer cells in AML and colon cancer models. PLoS ONE 2018, 13, e0191358.

95. Cekic, C.; Day, Y.-J.; Sag, D.; Linden, J. Myeloid expression of adenosine A2A receptor suppresses T and NK cell responses in the solid tumor microenvironment. Cancer Res. 2014, 74, 7250-7259. [CrossRef] [PubMed]

96. Mao, Y.; Sarhan, D.; Steven, A.; Seliger, B.; Kiessling, R.; Lundqvist, A. Inhibition of tumor-derived prostaglandin-e2 blocks the induction of myeloid-derived suppressor cells and recovers natural killer cell activity. Clin. Cancer Res. 2014, 20, 4096-4106. [CrossRef] [PubMed]

97. Sarhan, D.; Cichocki, F.; Zhang, B.; Yingst, A.; Spellman, S.R.; Cooley, S.; Verneris, M.R.; Blazar, B.R.; Miller, J.S. Adaptive NK Cells with Low TIGIT Expression Are Inherently Resistant to Myeloid-Derived Suppressor Cells. Cancer Res. 2016, 76, 5696-5706. [CrossRef] [PubMed]

98. Elkabets, M.; Ribeiro, V.S.G.; Dinarello, C.A.; Ostrand-Rosenberg, S.; Di Santo, J.P.; Apte, R.N.; Vosshenrich, C.A.J. IL-1 $\beta$ regulates a novel myeloid-derived suppressor cell subset that impairs NK cell development and function. Eur. J. Immunol. 2010, 40, 3347-3357. [CrossRef] [PubMed]

99. Goh, C.C.; Roggerson, K.M.; Lee, H.C. Hepatitis C virus-induced myeloid-derived suppressor cells suppress NK cell IFN- $\gamma$ production by altering cellular metabolism via arginase-1. J. Immunol. 2016, 196, 2283-2292. [CrossRef] [PubMed]

100. Hoechst, B.; Voigtlaender, T.; Ormandy, L.; Gamrekelashvili, J.; Zhao, F.; Wedemeyer, H.; Lehner, F.; Manns, M.P.; Greten, T.F.; Korangy, F. Myeloid derived suppressor cells inhibit natural killer cells in patients with hepatocellular carcinoma via the NKp30 receptor. Hepatology 2009, 50, 799-807. [CrossRef]

101. Tai, L.-H.; Alkayyal, A.A.; Leslie, A.L.; Sahi, S.; Bennett, S.; Tanese de Souza, C.; Baxter, K.; Angka, L.; Xu, R.; Kennedy, M.A.; et al. Phosphodiesterase- 5 inhibition reduces postoperative metastatic disease by targeting surgery-induced myeloid derived suppressor cell-dependent inhibition of Natural Killer cell cytotoxicity. Oncoimmunology 2018, 7, e1431082. [CrossRef]

102. Li, H.; Han, Y.; Guo, Q.; Zhang, M.; Cao, X. Cancer-expanded myeloid-derived suppressor cells induce anergy of NK cells through membrane-bound TGF-beta 1. J. Immunol. 2009, 182, 240-249. [CrossRef]

103. Bronte, V.; Brandau, S.; Chen, S.-H.; Colombo, M.P.; Frey, A.B.; Greten, T.F.; Mandruzzato, S.; Murray, P.J.; Ochoa, A.; Ostrand-Rosenberg, S.; et al. Recommendations for myeloid-derived suppressor cell nomenclature and characterization standards. Nat. Commun. 2016, 7, 12150. [CrossRef]

104. Wang, J.; Yang, L.; Yu, L.; Wang, Y.-Y.; Chen, R.; Qian, J.; Hong, Z.-P.; Su, X.-S. Surgery-induced monocytic myeloid-derived suppressor cells expand regulatory T cells in lung cancer. Oncotarget 2017, 8, 17050-17058. [CrossRef]

105. Manz, M.G.; Boettcher, S. Emergency granulopoiesis. Nat. Rev. Immunol. 2014, 14, 302-314. [CrossRef] [PubMed]

106. Loftus, T.J.; Mohr, A.M.; Moldawer, L.L. Dysregulated myelopoiesis and hematopoietic function following acute physiologic insult. Curr. Opin. Hematol. 2018, 25, 37-43. [CrossRef] [PubMed]

107. Hüsecken, Y.; Muche, S.; Kustermann, M.; Klingspor, M.; Palmer, A.; Braumüller, S.; Huber-Lang, M.; Debatin, K.-M.; Strauss, G. MDSCs are induced after experimental blunt chest trauma and subsequently alter antigen-specific T cell responses. Sci. Rep. 2017, 7, 12808. [CrossRef] [PubMed]

108. Xu, P.; He, H.; Gu, Y.; Wang, Y.; Sun, Z.; Yang, L.; Miao, C. Surgical trauma contributes to progression of colon cancer by downregulating CXCL4 and recruiting MDSCs. Exp. Cell Res. 2018, 370, 692-698. [CrossRef] [PubMed] 
109. Stiff, A.; Trikha, P.; Mundy-Bosse, B.; McMichael, E.; Mace, T.A.; Benner, B.; Kendra, K.; Campbell, A.; Gautam, S.; Abood, D.; et al. Nitric Oxide Production by Myeloid-Derived Suppressor Cells Plays a Role in Impairing Fc Receptor-Mediated Natural Killer Cell Function. Clin. Cancer Res. 2018, 24, 1891-1904. [CrossRef]

110. Zhu, X.; Herrera, G.; Ochoa, J.B. Immunosupression and infection after major surgery: A nutritional deficiency. Crit. Care Clin. 2010, 26, 491-500. [CrossRef]

111. Serafini, P.; Meckel, K.; Kelso, M.; Noonan, K.; Califano, J.; Koch, W.; Dolcetti, L.; Bronte, V.; Borrello, I. Phosphodiesterase- 5 inhibition augments endogenous antitumor immunity by reducing myeloid-derived suppressor cell function. J. Exp. Med. 2006, 203, 2691-2702. [CrossRef]

112. Auer, R.C. NCT02998736: PERIOP-04 Phase Ib Trial of Perioperative Tadalafil and Influenza Vaccination in Cancer Patients Undergoing Major Surgical Resection of a Primary Abdominal Malignancy. Available online: https: / / clinicaltrials.gov/ct2/ show / record/NCT02998736 (accessed on 26 October 2018).

113. Oberlies, J.; Watzl, C.; Giese, T.; Luckner, C.; Kropf, P.; Müller, I.; Ho, A.D.; Munder, M. Regulation of NK cell function by human granulocyte arginase. J. Immunol. 2009, 182, 5259-5267. [CrossRef]

114. Garvey, E.P.; Oplinger, J.A.; Furfine, E.S.; Kiff, R.J.; Laszlo, F.; Whittle, B.J.; Knowles, R.G. 1400 W is a slow, tight binding, and highly selective inhibitor of inducible nitric-oxide synthase in vitro and in vivo. J. Biol. Chem. 1997, 272, 4959-4963. [CrossRef] [PubMed]

115. Atochina-Vasserman, E.N.; Beers, M.F.; Kadire, H.; Tomer, Y.; Inch, A.; Scott, P.; Guo, C.J.; Gow, A.J. Selective inhibition of inducible NO synthase activity in vivo reverses inflammatory abnormalities in surfactant protein D-deficient mice. J. Immunol. 2007, 179, 8090-8097. [CrossRef] [PubMed]

116. Steggerda, S.M.; Bennett, M.K.; Chen, J.; Emberley, E.; Huang, T.; Janes, J.R.; Li, W.; MacKinnon, A.L.; Makkouk, A.; Marguier, G.; et al. Inhibition of arginase by CB-1158 blocks myeloid cell-mediated immune suppression in the tumor microenvironment. J. Immunother. Cancer 2017, 5, 101. [CrossRef]

117. Papadopoulos, K.P.; Tsai, F.Y.-C.; Bauer, T.M.; Muigai, L.; Liang, Y.; Bennett, M.K.; Orford, K.W.; Fu, S. CX-1158-101: A first-in-human phase 1 study of CB-1158, a small molecule inhibitor of arginase, as monotherapy and in combination with an anti-PD-1 checkpoint inhibitor in patients (pts) with solid tumors. J. Clin. Orthod. 2017, 35, 3005. [CrossRef]

118. Tsai, F.; Bauer, T.; Naing, A. NCT02903914: Arginase Inhibitor INCB001158 as a Single Agent and in Combination with Immune Checkpoint Therapy in Patients with Advanced/Metastatic Solid Tumors. Available online: https:/ / clinicaltrials.gov/ct2/show/record/NCT02903914 (accessed on 26 October 2018).

119. Campbell, L.; Saville, C.R.; Murray, P.J.; Cruickshank, S.M.; Hardman, M.J. Local arginase 1 activity is required for cutaneous wound healing. J. Investig. Dermatol. 2013, 133, 2461-2470. [CrossRef]

120. Gould, A.; Candy, G.P. Arginine metabolism and wound healing: Basic science review. Wound Heal. S. Afr. 2008, 1, 48-50.

121. Alexander, J.W.; Supp, D.M. Role of Arginine and Omega-3 Fatty Acids in Wound Healing and Infection. Adv. Wound Care 2014, 3, 682-690. [CrossRef] [PubMed]

122. Heyland, D.K.; Novak, F.; Drover, J.W.; Jain, M.; Su, X.; Suchner, U. Should immunonutrition become routine in critically ill patients? A systematic review of the evidence. JAMA 2001, 286, 944-953. [CrossRef]

123. Heine, A.; Flores, C.; Gevensleben, H.; Diehl, L.; Heikenwalder, M.; Ringelhan, M.; Janssen, K.-P.; Nitsche, U.; Garbi, N.; Brossart, P.; et al. Targeting myeloid derived suppressor cells with all-trans retinoic acid is highly time-dependent in therapeutic tumor vaccination. Oncoimmunology 2017, 6, e1338995. [CrossRef] [PubMed]

124. Saito, Y.; Shimada, M.; Utsunomiya, T.; Morine, Y.; Imura, S.; Ikemoto, T.; Mori, H.; Hanaoka, J.; Iwahashi, S.; Yamada, S.; et al. Regulatory T cells in the blood: A new marker of surgical stress. Surg. Today 2013, 43, 608-612. [CrossRef] [PubMed]

125. Najafi, M.; Farhood, B.; Mortezaee, K. Contribution of regulatory T cells to cancer: A review. J. Cell. Physiol. 2018. [CrossRef] [PubMed]

126. Ino, Y.; Yamazaki-Itoh, R.; Shimada, K.; Iwasaki, M.; Kosuge, T.; Kanai, Y.; Hiraoka, N. Immune cell infiltration as an indicator of the immune microenvironment of pancreatic cancer. Br. J. Cancer 2013, 108, 914-923. [CrossRef] [PubMed]

127. Zhang, S.; Pan, S.; Lyu, Q.; Wu, P.; Qin, G.; Wang, Q.; He, Z.; He, X.; Wu, M.; Chen, G. Postoperative Regulatory T-Cells and Natural Killer Cells in Stage I Nonsmall Cell Lung Cancer Underwent Video-assisted Thoracoscopic Lobectomy or Thoracotomy. Chin. Med. J. (Engl.) 2015, 128, 1502-1509. [PubMed] 
128. Tang, Y.; Xu, X.; Guo, S.; Zhang, C.; Tang, Y.; Tian, Y.; Ni, B.; Lu, B.; Wang, H. An increased abundance of tumor-infiltrating regulatory $\mathrm{T}$ cells is correlated with the progression and prognosis of pancreatic ductal adenocarcinoma. PLoS ONE 2014, 9, e91551. [CrossRef] [PubMed]

129. Littwitz-Salomon, E.; Malyshkina, A.; Schimmer, S.; Dittmer, U. The Cytotoxic Activity of Natural Killer Cells Is Suppressed by IL-10+ Regulatory T Cells During Acute Retroviral Infection. Front. Immunol. 2018, 9, 1947. [CrossRef] [PubMed]

130. Chen, C.; Chen, D.; Zhang, Y.; Chen, Z.; Zhu, W.; Zhang, B.; Wang, Z.; Le, H. Changes of CD4+CD25+FOXP3+ and CD8+CD28- regulatory T cells in non-small cell lung cancer patients undergoing surgery. Int. Immunopharmacol. 2014, 18, 255-261. [CrossRef] [PubMed]

131. Zhou, L.; Li, Y.; Li, X.; Chen, G.; Liang, H.; Wu, Y.; Tong, J.; Ouyang, W. Propranolol Attenuates Surgical Stress-Induced Elevation of the Regulatory T Cell Response in Patients Undergoing Radical Mastectomy. J. Immunol. 2016, 196, 3460-3469. [CrossRef] [PubMed]

132. Li, Y.; Zhou, L.; Sun, B.; Li, X.; Duan, K.; Wu, Y.; Ouyang, W. Interleukin-2 administration after modified radical mastectomy in breast cancer therapy increases peripheral regulatory T cells. Int. J. Clin. Exp. Med. 2015, 8, 7816-7822. [PubMed]

133. Pedroza-Pacheco, I.; Madrigal, A.; Saudemont, A. Interaction between natural killer cells and regulatory T cells: Perspectives for immunotherapy. Cell. Mol. Immunol. 2013, 10, 222-229. [CrossRef] [PubMed]

134. Littwitz-Salomon, E.; Akhmetzyanova, I.; Vallet, C.; Francois, S.; Dittmer, U.; Gibbert, K. Activated regulatory T cells suppress effector NK cell responses by an IL-2-mediated mechanism during an acute retroviral infection. Retrovirology 2015, 12, 66. [CrossRef] [PubMed]

135. Kohm, A.P.; Sanders, V.M. Norepinephrine and beta 2-adrenergic receptor stimulation regulate CD4+ T and B lymphocyte function in vitro and in vivo. Pharmacol. Rev. 2001, 53, 487-525. [PubMed]

136. Madden, K.S. Catecholamines, sympathetic innervation, and immunity. Brain Behav. Immun. 2003, 17 (Suppl. 1), S5-S10. [CrossRef]

137. Xiang, L.; Marshall, G.D., Jr. Immunomodulatory effects of in vitro stress hormones on FoxP3, Th1/Th2 cytokine and costimulatory molecule mRNA expression in human peripheral blood mononuclear cells. Neuroimmunomodulation 2011, 18, 1-10. [CrossRef] [PubMed]

138. Ng, T.H.S.; Britton, G.J.; Hill, E.V.; Verhagen, J.; Burton, B.R.; Wraith, D.C. Regulation of adaptive immunity; the role of interleukin-10. Front. Immunol. 2013, 4, 129. [CrossRef] [PubMed]

139. Klatte, T.; Ittenson, A.; Röhl, F.-W.; Ecke, M.; Allhoff, E.P.; Böhm, M. Perioperative immunomodulation with interleukin-2 in patients with renal cell carcinoma: Results of a controlled phase II trial. Br. J. Cancer 2006, 95, 1167-1173. [CrossRef] [PubMed]

140. Böhm, M.; Ittenson, A.; Schierbaum, K.F.; Röhl, F.-W.; Ansorge, S.; Allhoff, E.P. Pretreatment with interleukin-2 modulates peri-operative immuno-dysfunction in patients with renal cell carcinoma. Eur. Urol. 2002, 41, 458-467. [CrossRef]

141. Romano, F.; Garancini, M.; Uggeri, F.; Degrate, L.; Nespoli, L.; Gianotti, L.; Nespoli, A.; Uggeri, F. Surgical treatment of liver metastases of gastric cancer: State of the art. World J. Surg. Oncol. 2012, 10, 157. [CrossRef]

142. Taylor, N.A.; Vick, S.C.; Iglesia, M.D.; Brickey, W.J.; Midkiff, B.R.; McKinnon, K.P.; Reisdorf, S.; Anders, C.K.; Carey, L.A.; Parker, J.S.; et al. Treg depletion potentiates checkpoint inhibition in claudin-low breast cancer. J. Clin. Investig. 2017, 127, 3472-3483. [CrossRef]

143. Klages, K.; Mayer, C.T.; Lahl, K.; Loddenkemper, C.; Teng, M.W.L.; Ngiow, S.F.; Smyth, M.J.; Hamann, A.; Huehn, J.; Sparwasser, T. Selective depletion of Foxp3+ regulatory T cells improves effective therapeutic vaccination against established melanoma. Cancer Res. 2010, 70, 7788-7799. [CrossRef]

144. Leao, I.C.; Ganesan, P.; Armstrong, T.D.; Jaffee, E.M. Effective depletion of regulatory T cells allows the recruitment of mesothelin-specific CD8 $\mathrm{T}$ cells to the antitumor immune response against a mesothelin-expressing mouse pancreatic adenocarcinoma. Clin. Transl. Sci. 2008, 1, 228-239. [CrossRef]

145. Mahnke, K.; Schönfeld, K.; Fondel, S.; Ring, S.; Karakhanova, S.; Wiedemeyer, K.; Bedke, T.; Johnson, T.S.; Storn, V.; Schallenberg, S.; et al. Depletion of CD4+CD25+ human regulatory T cells in vivo: Kinetics of Treg depletion and alterations in immune functions in vivo and in vitro. Int. J. Cancer 2007, 120, 2723-2733. [CrossRef] [PubMed]

146. Bielekova, B. Daclizumab therapy for multiple sclerosis. Neurotherapeutics 2013, 10, 55-67. [CrossRef] [PubMed] 
147. Berkowitz, J.L.; Janik, J.E.; Stewart, D.M.; Jaffe, E.S.; Stetler-Stevenson, M.; Shih, J.H.; Fleisher, T.A.; Turner, M.; Urquhart, N.E.; Wharfe, G.H.; et al. Safety, efficacy, and pharmacokinetics/pharmacodynamics of daclizumab (anti-CD25) in patients with adult T-cell leukemia/lymphoma. Clin. Immunol. 2014, 155, 176-187. [CrossRef] [PubMed]

148. Dickson, R. NCT00109161: A Phase II Randomized, Double-Blinded, Placebo-Controlled, Multi-Center Study of Subcutaneous Daclizumab in Patients with Active, Relapsing Forms of Multiple Sclerosis. Available online: https: / / clinicaltrials.gov/ct2/show/record/NCT0010+161 (accessed on 26 October 2018).

149. Shoup, M. NCT00726037: A Pilot Study Evaluating the Efficacy of Regulatory T-Cell (T-Reg) Suppression by Denileukin Diftitox (Ontak) in Metastatic Pancreatic Cancer. Available online: https:/ / clinicaltrials.gov/ct2/ show / record/NCT00726037 (accessed on 26 October 2018).

150. Huss, D.J.; Mehta, D.S.; Sharma, A.; You, X.; Riester, K.A.; Sheridan, J.P.; Amaravadi, L.S.; Elkins, J.S.; Fontenot, J.D. In vivo maintenance of human regulatory T cells during CD25 blockade. J. Immunol. 2015, 194, 84-92. [CrossRef] [PubMed]

151. Ghiringhelli, F.; Menard, C.; Puig, P.E.; Ladoire, S.; Roux, S.; Martin, F.; Solary, E.; Le Cesne, A.; Zitvogel, L.; Chauffert, B. Metronomic cyclophosphamide regimen selectively depletes CD4+CD25+ regulatory T cells and restores $\mathrm{T}$ and NK effector functions in end stage cancer patients. Cancer Immunol. Immunother. 2007, 56, 641-648. [CrossRef]

152. Bachireddy, P. NCT03219450: A Pilot Study of a Personalized Neoantigen Cancer Vaccine with and without Low-Dose Cyclophosphamide in Treatment Naïve, Asymptomatic Patients with IGHV Unmutated Chronic Lymphocytic Leukemia. Available online: https://clinicaltrials.gov/ct2/show/record/NCT03219450 (accessed on 26 October 2018).

153. Lee, S.-H.; Fragoso, M.F.; Biron, C.A. Cutting edge: A novel mechanism bridging innate and adaptive immunity: IL-12 induction of CD25 to form high-affinity IL-2 receptors on NK cells. J. Immunol. 2012, 189, 2712-2716. [CrossRef] [PubMed]

154. Paul, S.; Lal, G. The Molecular Mechanism of Natural Killer Cells Function and Its Importance in Cancer Immunotherapy. Front. Immunol. 2017, 8, 1124. [CrossRef] [PubMed]

155. Deng, W.; Gowen, B.G.; Zhang, L.; Wang, L.; Lau, S.; Iannello, A.; Xu, J.; Rovis, T.L.; Xiong, N.; Raulet, D.H. Antitumor immunity. A shed NKG2D ligand that promotes natural killer cell activation and tumor rejection. Science 2015, 348, 136-139. [CrossRef]

156. Molfetta, R.; Quatrini, L.; Santoni, A.; Paolini, R. Regulation of NKG2D-Dependent NK Cell Functions: The Yin and the Yang of Receptor Endocytosis. Int. J. Mol. Sci. 2017, 18. [CrossRef]

157. Gasser, S.; Orsulic, S.; Brown, E.J.; Raulet, D.H. The DNA damage pathway regulates innate immune system ligands of the NKG2D receptor. Nature 2005, 436, 1186-1190. [CrossRef]

158. Eissmann, P.; Evans, J.H.; Mehrabi, M.; Rose, E.L.; Nedvetzki, S.; Davis, D.M. Multiple mechanisms downstream of TLR-4 stimulation allow expression of NKG2D ligands to facilitate macrophage/NK cell crosstalk. J. Immunol. 2010, 184, 6901-6909. [CrossRef] [PubMed]

159. Bui, J.D.; Carayannopoulos, L.N.; Lanier, L.L.; Yokoyama, W.M.; Schreiber, R.D. IFN-dependent down-regulation of the NKG2D ligand H60 on tumors. J. Immunol. 2006, 176, 905-913. [CrossRef] [PubMed]

160. Valés-Gómez, M.; Chisholm, S.E.; Cassady-Cain, R.L.; Roda-Navarro, P.; Reyburn, H.T. Selective induction of expression of a ligand for the NKG2D receptor by proteasome inhibitors. Cancer Res. 2008, 68, 1546-1554. [CrossRef] [PubMed]

161. Skov, S.; Pedersen, M.T.; Andresen, L.; Straten, P.T.; Woetmann, A.; Ødum, N. Cancer Cells Become Susceptible to Natural Killer Cell Killing after Exposure to Histone Deacetylase Inhibitors Due to Glycogen Synthase Kinase-3-Dependent Expression of MHC Class I-Related Chain A and B. Cancer Res. 2005, 65, 11136-11145. [CrossRef] [PubMed]

162. Semeraro, M.; Rusakiewicz, S.; Minard-Colin, V.; Delahaye, N.F.; Enot, D.; Vély, F.; Marabelle, A.; Papoular, B.; Piperoglou, C.; Ponzoni, M.; et al. Clinical impact of the NKp30/B7-H6 axis in high-risk neuroblastoma patients. Sci. Transl. Med. 2015, 7, 283ra55. [CrossRef] [PubMed]

163. Garni-Wagner, B.A.; Purohit, A.; Mathew, P.A.; Bennett, M.; Kumar, V. A novel function-associated molecule related to non-MHC-restricted cytotoxicity mediated by activated natural killer cells and T cells. J. Immunol. 1993, 151, 60-70. [PubMed]

164. Makkouk, A.; Chester, C.; Kohrt, H.E. Rationale for anti-CD137 cancer immunotherapy. Eur. J. Cancer 2016, 54, 112-119. [CrossRef] 
165. Kohrt, H.E.; Houot, R.; Goldstein, M.J.; Weiskopf, K.; Alizadeh, A.A.; Brody, J.; Müller, A.; Pachynski, R.; Czerwinski, D.; Coutre, S.; et al. CD137 stimulation enhances the antilymphoma activity of anti-CD20 antibodies. Blood 2011, 117, 2423-2432. [CrossRef]

166. Kohrt, H.E.; Colevas, A.D.; Houot, R.; Weiskopf, K.; Goldstein, M.J.; Lund, P.; Mueller, A.; Sagiv-Barfi, I.; Marabelle, A.; Lira, R.; et al. Targeting CD137 enhances the efficacy of cetuximab. J. Clin. Investig. 2014, 124, 2668-2682. [CrossRef]

167. Vitale, M.; Falco, M.; Castriconi, R.; Parolini, S.; Zambello, R.; Semenzato, G.; Biassoni, R.; Bottino, C.; Moretta, L.; Moretta, A. Identification of NKp80, a novel triggering molecule expressed by human NK cells. Eur. J. Immunol. 2001, 31, 233-242. [CrossRef]

168. He, L.-Z.; Prostak, N.; Thomas, L.J.; Vitale, L.; Weidlick, J.; Crocker, A.; Pilsmaker, C.D.; Round, S.M.; Tutt, A.; Glennie, M.J.; et al. Agonist anti-human CD27 monoclonal antibody induces T cell activation and tumor immunity in human CD27-transgenic mice. J. Immunol. 2013, 191, 4174-4183. [CrossRef] [PubMed]

169. Burris, H.A.; Infante, J.R.; Ansell, S.M.; Nemunaitis, J.J.; Weiss, G.R.; Villalobos, V.M.; Sikic, B.I.; Taylor, M.H.; Northfelt, D.W.; Carson, W.E., 3rd; et al. Safety and Activity of Varlilumab, a Novel and First-in-Class Agonist Anti-CD27 Antibody, in Patients with Advanced Solid Tumors. J. Clin. Oncol. 2017, 35, 2028-2036. [CrossRef] [PubMed]

170. Hofer, E.; Koehl, U. Natural Killer Cell-Based Cancer Immunotherapies: From Immune Evasion to Promising Targeted Cellular Therapies. Front. Immunol. 2017, 8, 745. [CrossRef]

171. Bristol-MyersSquibb NCT01750580: A Phase 1 Study of BMS-986015, an Anti-KIR Monoclonal Antibody, Administered with Ipilimumab, an Anti-CTLA4 Monoclonal Antibody, in Subjects with Select Advanced Solid Tumors. Available online: https:/ / clinicaltrials.gov/ct2/show / record/NCT01750580 (accessed on 26 October 2018).

172. Bristol-MyersSquibb NCT01714739: A Phase 1/2 Study of the Combination of Lirilumab (Anti-KIR) Plus Nivolumab (Anti-PD-1) or Lirilumab Plus Nivolumab and Ipilimumab in Advanced Refractory Solid Tumors. Available online: https: / clinicaltrials.gov/ct2/show / record/NCT01714739 (accessed on 26 October 2018).

173. Gallois, A.; Silva, I.; Osman, I.; Bhardwaj, N. Reversal of natural killer cell exhaustion by TIM-3 blockade. Oncoimmunology 2014, 3, e946365. [CrossRef] [PubMed]

174. Hsu, J.; Hodgins, J.J.; Marathe, M.; Nicolai, C.J.; Bourgeois-Daigneault, M.-C.; Trevino, T.N.; Azimi, C.S.; Scheer, A.K.; Randolph, H.E.; Thompson, T.W.; et al. Contribution of NK cells to immunotherapy mediated by PD-1/PD-L1 blockade. J. Clin. Investig. 2018, 128, 4654-4668. [CrossRef] [PubMed]

175. Oyer, J.; Gitto, S.B.; Altomare, D.; Igarashi, R.; Copik, A. Effect of PDL1 signaling blockade on NK cell cytolytic activity towards ovarian cancer. J. Clin. Orthod. 2018, 36, 13. [CrossRef]

176. Benson, D.M., Jr.; Bakan, C.E.; Mishra, A.; Hofmeister, C.C.; Efebera, Y.; Becknell, B.; Baiocchi, R.A.; Zhang, J.; Yu, J.; Smith, M.K.; et al. The PD-1/PD-L1 axis modulates the natural killer cell versus multiple myeloma effect: A therapeutic target for CT-011, a novel monoclonal anti-PD-1 antibody. Blood 2010, 116, 2286-2294. [CrossRef]

177. Hotchkiss, R.S.; Monneret, G.; Payen, D. Immunosuppression in sepsis: A novel understanding of the disorder and a new therapeutic approach. Lancet Infect. Dis. 2013, 13, 260-268. [CrossRef]

178. Angka, L.; Khan, S.T.; Kilgour, M.K.; Xu, R.; Kennedy, M.A.; Auer, R.C. Dysfunctional Natural Killer Cells in the Aftermath of Cancer Surgery. Int. J. Mol. Sci. 2017, 18. [CrossRef]

179. Islam, M.N.; Bradley, B.A.; Ceredig, R. Sterile post-traumatic immunosuppression. Clin. Transl. Immunol. 2016, 5, e77. [CrossRef]

180. Auer, R.C. NCT02987296: A Translational Clinical Trial of Perioperative Immunonutrition in Colorectal Cancer Patients Undergoing Abdominal Surgery: PERIOP-02. Available online: https:/ clinicaltrials.gov/ ct2/show / record/NCT02987296 (accessed on 26 October 2018).

181. Mehrotra, P.T.; Donnelly, R.P.; Wong, S.; Kanegane, H.; Geremew, A.; Mostowski, H.S.; Furuke, K.; Siegel, J.P.; Bloom, E.T. Production of IL-10 by Human Natural Killer Cells Stimulated with IL-2 and/or IL-12. J. Immunol. 1998, 160, 2637-2644. [PubMed]

182. Jiang, Y.; Yang, M.; Sun, X.; Chen, X.; Ma, M.; Yin, X.; Qian, S.; Zhang, Z.; Fu, Y.; Liu, J.; et al. IL-10+ NK and TGF- $\beta+$ NK cells play negative regulatory roles in HIV infection. BMC Infect. Dis. 2018, 18, 80. [CrossRef] [PubMed]

183. Moore, K.W.; de Waal Malefyt, R.; Coffman, R.L.; O'Garra, A. Interleukin-10 and the interleukin-10 receptor. Annu. Rev. Immunol. 2001, 19, 683-765. [CrossRef] [PubMed] 
184. Terme, M.; Ullrich, E.; Aymeric, L.; Meinhardt, K.; Coudert, J.D.; Desbois, M.; Ghiringhelli, F.; Viaud, S.; Ryffel, B.; Yagita, H.; et al. Cancer-induced immunosuppression: IL-18-elicited immunoablative NK cells. Cancer Res. 2012, 72, 2757-2767. [CrossRef] [PubMed]

185. Perona-Wright, G.; Mohrs, K.; Szaba, F.M.; Kummer, L.W.; Madan, R.; Karp, C.L.; Johnson, L.L.; Smiley, S.T.; Mohrs, M. Systemic but not local infections elicit immunosuppressive IL-10 production by natural killer cells. Cell Host Microbe 2009, 6, 503-512. [CrossRef] [PubMed]

186. Wu, Y.; Tian, Z.; Wei, H. Developmental and Functional Control of Natural Killer Cells by Cytokines. Front. Immunol. 2017, 8, 930. [CrossRef] [PubMed]

187. Zeng, J.; Tang, S.Y.; Toh, L.L.; Wang, S. Generation of “Off-the-Shelf” Natural Killer Cells from Peripheral Blood Cell-Derived Induced Pluripotent Stem Cells. Stem Cell Rep. 2017, 9, 1796-1812. [CrossRef]

188. Dahlberg, C.I.M.; Sarhan, D.; Chrobok, M.; Duru, A.D.; Alici, E. Natural Killer Cell-Based Therapies Targeting Cancer: Possible Strategies to Gain and Sustain Anti-Tumor Activity. Front. Immunol. 2015, 6, 605. [CrossRef]

189. Granzin, M.; Wagner, J.; Köhl, U.; Cerwenka, A.; Huppert, V.; Ullrich, E. Shaping of Natural Killer Cell Antitumor Activity by Ex Vivo Cultivation. Front. Immunol. 2017, 8, 458. [CrossRef]

190. Sakamoto, N.; Ishikawa, T.; Kokura, S.; Okayama, T.; Oka, K.; Ideno, M.; Sakai, F.; Kato, A.; Tanabe, M.; Enoki, T.; et al. Phase I clinical trial of autologous NK cell therapy using novel expansion method in patients with advanced digestive cancer. J. Transl. Med. 2015, 13, 277. [CrossRef]

191. Miller, J.S.; Oelkers, S.; Verfaillie, C.; McGlave, P. Role of monocytes in the expansion of human activated natural killer cells. Blood 1992, 80, 2221-2229. [PubMed]

192. Luhm, J.; Brand, J.-M.; Koritke, P.; Höppner, M.; Kirchner, H.; Frohn, C. Large-scale generation of natural killer lymphocytes for clinical application. J. Hematother. Stem Cell Res. 2002, 11, 651-657. [CrossRef] [PubMed]

193. Nguyen, S.; Kuentz, M.; Vernant, J.-P.; Dhedin, N.; Bories, D.; Debré, P.; Vieillard, V. Involvement of mature donor $\mathrm{T}$ cells in the NK cell reconstitution after haploidentical hematopoietic stem-cell transplantation. Leukemia 2008, 22, 344-352. [CrossRef] [PubMed]

194. Berg, M.; Lundqvist, A.; McCoy, P., Jr.; Samsel, L.; Fan, Y.; Tawab, A.; Childs, R. Clinical-grade ex vivo-expanded human natural killer cells up-regulate activating receptors and death receptor ligands and have enhanced cytolytic activity against tumor cells. Cytotherapy 2009, 11, 341-355. [CrossRef]

195. Siegler, U.; Meyer-Monard, S.; Jörger, S.; Stern, M.; Tichelli, A.; Gratwohl, A.; Wodnar-Filipowicz, A.; Kalberer, C.P. Good manufacturing practice-compliant cell sorting and large-scale expansion of single KIR-positive alloreactive human natural killer cells for multiple infusions to leukemia patients. Cytotherapy 2010, 12, 750-763. [CrossRef]

196. Spanholtz, J.; Preijers, F.; Tordoir, M.; Trilsbeek, C.; Paardekooper, J.; de Witte, T.; Schaap, N.; Dolstra, H. Clinical-grade generation of active NK cells from cord blood hematopoietic progenitor cells for immunotherapy using a closed-system culture process. PLoS ONE 2011, 6, e20740. [CrossRef] [PubMed]

197. Woll, P.S.; Grzywacz, B.; Tian, X.; Marcus, R.K.; Knorr, D.A.; Verneris, M.R.; Kaufman, D.S. Human embryonic stem cells differentiate into a homogeneous population of natural killer cells with potent in vivo antitumor activity. Blood 2009, 113, 6094-6101. [CrossRef] [PubMed]

198. Knorr, D.A.; Ni, Z.; Hermanson, D.; Hexum, M.K.; Bendzick, L.; Cooper, L.J.N.; Lee, D.A.; Kaufman, D.S. Clinical-scale derivation of natural killer cells from human pluripotent stem cells for cancer therapy. Stem Cells Transl. Med. 2013, 2, 274-283. [CrossRef]

199. Kruse, V.; Hamann, C.; Monecke, S.; Cyganek, L.; Elsner, L.; Hübscher, D.; Walter, L.; Streckfuss-Bömeke, K.; Guan, K.; Dressel, R. Human Induced Pluripotent Stem Cells Are Targets for Allogeneic and Autologous Natural Killer (NK) Cells and Killing Is Partly Mediated by the Activating NK Receptor DNAM-1. PLoS ONE 2015, 10, e0125544. [CrossRef] [PubMed]

200. Klingemann, H.; Boissel, L.; Toneguzzo, F. Natural Killer Cells for Immunotherapy-Advantages of the NK-92 Cell Line over Blood NK Cells. Front. Immunol. 2016, 7, 91. [CrossRef]

201. Eguizabal, C.; Zenarruzabeitia, O.; Monge, J.; Santos, S.; Vesga, M.A.; Maruri, N.; Arrieta, A.; Riñón, M.; Tamayo-Orbegozo, E.; Amo, L.; et al. Natural killer cells for cancer immunotherapy: Pluripotent stem cells-derived NK cells as an immunotherapeutic perspective. Front. Immunol. 2014, 5, 439. [CrossRef] [PubMed] 
202. Boyiadzis, M. NCT00900809: Phase I Study of Adoptive Immunotherapy Using the Natural Killer Cell Line, Neukoplast ${ }^{\mathrm{TM}}$ (NK-92), for the Treatment of Refractory or Relapsed Acute Myeloid Leukemia. Available online: https: / / clinicaltrials.gov/ct2/show / record/NCT00900809 (accessed on 26 October 2018).

203. Keating, A. NCT00990717: A Dose Escalation Study of NK-92 Cell Infusions in Patients with Hematological Malignancies in Relapse after Autologous Stem Cell Transplantation. Available online: https: / clinicaltrials. gov/ct2/show / record/NCT00990717 (accessed on 26 October 2018).

204. NantKwest, Inc. NCT02465957: Phase 2 Study of aNK (Activated NK-92 Natural Killer Cells) Infusions in Combination with ALT-803 (IL-15) in Patients with Stage III (IIIB) or Stage IV Merkel Cell Carcinoma (MCC). Available online: https:/ / clinicaltrials.gov/ct2/show/record/NCT02465957 (accessed on 26 October 2018).

205. Cooper, M.A.; Bush, J.E.; Fehniger, T.A.; VanDeusen, J.B.; Waite, R.E.; Liu, Y.; Aguila, H.L.; Caligiuri, M.A. In vivo evidence for a dependence on interleukin 15 for survival of natural killer cells. Blood 2002, 100, 3633-3638. [CrossRef] [PubMed]

206. De Rham, C.; Ferrari-Lacraz, S.; Jendly, S.; Schneiter, G.; Dayer, J.-M.; Villard, J. The proinflammatory cytokines IL-2, IL-15 and IL-21 modulate the repertoire of mature human natural killer cell receptors. Arthritis Res. Ther. 2007, 9, R125. [CrossRef] [PubMed]

207. Weber, J.S.; Rosenberg, S.A. Modulation of murine tumor major histocompatibility antigens by cytokines in vivo and in vitro. Cancer Res. 1988, 48, 5818-5824. [PubMed]

208. Nagashima, S.; Mailliard, R.; Kashii, Y.; Reichert, T.E.; Herberman, R.B.; Robbins, P.; Whiteside, T.L. Stable transduction of the interleukin-2 gene into human natural killer cell lines and their phenotypic and functional characterization in vitro and in vivo. Blood 1998, 91, 3850-3861.

209. Li, Y.; Hermanson, D.L.; Moriarity, B.S.; Kaufman, D.S. Human iPSC-Derived Natural Killer Cells Engineered with Chimeric Antigen Receptors Enhance Anti-tumor Activity. Cell Stem Cell 2018, 23, 181-192. [CrossRef]

(C) 2018 by the authors. Licensee MDPI, Basel, Switzerland. This article is an open access article distributed under the terms and conditions of the Creative Commons Attribution (CC BY) license (http:/ / creativecommons.org/licenses/by/4.0/). 